\section{(A) Check for updates}

Cite this: Dalton Trans., 2019, 48, 16922

Received 4th September 2019, Accepted 24th September 2019

DOI: 10.1039/c9dt03577j

rsc.li/dalton

\title{
Structure-property-reactivity studies on dithiaphospholestt:
}

\author{
Darren M. C. Ould, ${ }^{a}$ Thao T. P. Tran, ${ }^{\mathrm{b}}$ Jeremy M. Rawson (D)*b and \\ Rebecca L. Melen (D) *a
}

\begin{abstract}
The reaction of either toluene-3,4-dithiol or benzene dithiol with phosphorus(III) trihalides generates the corresponding benzo-fused 1,3,2-dithiaphospholes, $\mathrm{RC}_{6} \mathrm{H}_{3} \mathrm{~S}_{2} \mathrm{PX}(\mathrm{R}=\mathrm{Me}(\mathbf{1}), \mathrm{R}=\mathrm{H}(\mathbf{2}) ; \mathrm{X}=\mathrm{Cl}, \mathrm{Br}, \mathrm{I})$. The P-chloro-dithiaphospholes undergo: (a) halogen abstraction reactions with Lewis acids forming phosphenium cations; (b) substitution with LiHMDS base and; (c) reduction chemistry with sodium metal to generate the $\mathrm{P}-\mathrm{P} \sigma$-bonded dimer, $\left(\mathrm{RC}_{6} \mathrm{H}_{3} \mathrm{~S}_{2} \mathrm{P}\right)_{2}$. Reduction catalysis of aldehydes with pinacolborane using dithiaphospholes is compared with their dioxaphosphole and diazaphosphole counterparts as precatalysts, revealing interesting differences in the reactivity of this series of compounds.
\end{abstract}

\section{Introduction}

In the last few decades there has been a renaissance in main group chemistry stemming from the emerging materials applications of main group compounds ${ }^{1}$ alongside increasing applications as reagents and catalysts in organic synthesis. ${ }^{2}$ In all these areas, performance is being enhanced by the inclusion of main group elements or main-group functional groups to tailor electron-donating or withdrawing properties, enhancing donor or acceptor ability, redox behaviour or Lewis acidity inter alia. For example, in materials chemistry responsive organoboron based luminescent materials ${ }^{3}$ and main group perovskites for solar cell applications ${ }^{4}$ have attracted considerable attention. For the later p-block elements the redox active nature of many electron-rich $\mathrm{S} / \mathrm{N}$ and Se/N-based heterocycles have led to the discovery of some of the highest magnetic ordering temperatures for organic magnets, ${ }^{5}$ as well as molecule-based conductors ${ }^{6}$ and as redox active paramagnetic ligands inter alia. $^{7}$ Alongside this, the ability to tune the Lewis acidity of early p-block elements has attracted attention in main group promoted or catalysed organic transformations ${ }^{8,9}$ while frustrated Lewis pair (FLP) combinations continue to

\footnotetext{
${ }^{a}$ Cardiff Catalysis Institute, School of Chemistry, Cardiff University, Main Building, Cardiff, CF10 3AT, Cymru/Wales, UK. E-mail: melenr@cardiff.ac.uk

${ }^{b}$ Department of Chemistry and Biochemistry, University of Windsor,

401 Sunset Avenue, Windsor, Canada.E-mail: jmrawson@uwindsor.ca

$\dagger$ Information about the data that underpins the results presented in this article, including how to access them, can be found in the Cardiff University data catalogue at http://doi.org/10.17035/d.2019.0084454664

\$Electronic supplementary information (ESI) available: X-ray data, NMR spectra. CCDC 1951113-1951115, 1951125-1951127, 1951132, 1430534 and 824860. For ESI and crystallographic data in CIF or other electronic format see DOI: 10.1039/ c9dt03577j
}

activate a diverse range of small gas molecules including $\mathrm{CO}_{2}$ and dihydrogen. ${ }^{10}$

Among the many aspects of main group chemistry, there has been increasing use of heterocyclic phosphorus compounds as catalysts for organic transformations, exemplified by work by Zhang et al. on the nucleophilicity of diazaphospholene hydrides. ${ }^{11}$ Gudat first showed the hydridic nature of the $\mathrm{P}-\mathrm{H}$ bond in 1,3,2-diazaphospholenes (Scheme 1 top, $\mathrm{X}=\mathrm{H}),{ }^{12}$ which have been used in stoichiometric reduction reactions ${ }^{13}$ and more recently by Kinjo in the catalytic hydrogenation of the $\mathrm{N}=\mathrm{N}$ double bond with ammonia borane ${ }^{14}$ as well as the catalytic hydroboration of carbonyl compounds
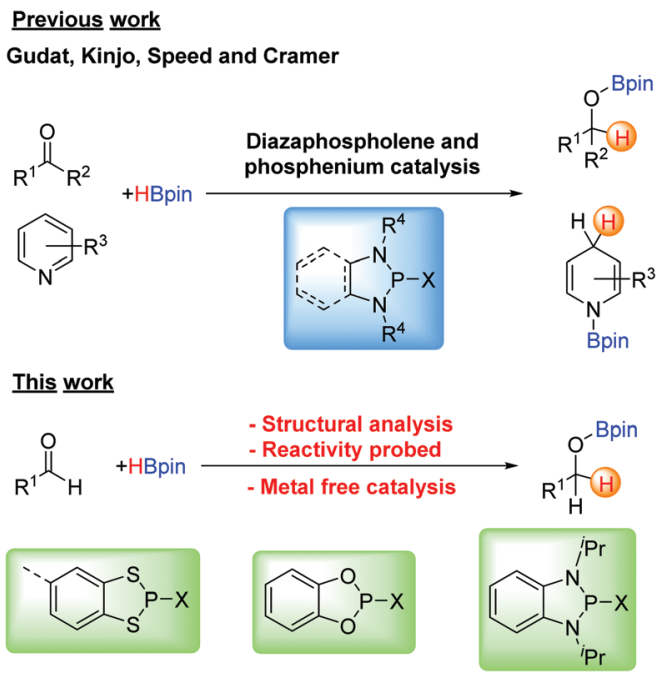

Scheme 1 Previous use of diazaphospholenes for catalysis (Top) and this work (Bottom). 
with pinacolborane. ${ }^{15}$ Speed has also used 1,2,4,3-triazaphospholenes for the catalytic hydroboration of various carbonyl compounds, ${ }^{16}$ and reported the first use of diazaphospholenes as chiral catalysts by introducing chirality at the $\mathrm{R}$ group on the nitrogen atoms. ${ }^{17}$ The Cramer group has also used 1,3,2diazaphospholenes for chiral reductive chemistry. ${ }^{18}$ The related phosphenium cations have also been used as pre-catalysts in the reduction of pyridines and imines with pinacolborane or silanes. ${ }^{19,20}$

The ability to tailor the reaction chemistry through application of the isolobal analogy gives rise to a large number of heterocycles closely related to the diazaphosphole unit. This includes replacement of $\mathrm{P}$ by heavier pnictogens such as $\mathrm{As}^{21}$ and one of our groups have recently identified that benzofused diaza-chloro-arsole is highly active for the reduction of aldehydes with pinacolborane. ${ }^{22}$ Conversely replacement of $\mathrm{R}-\mathrm{N}$ by isolobal chalcogens leads to heterocycles such as the dioxaphospholes and dithiaphospholes (Scheme 1, bottom).

In the current study we report the syntheses, structures and reactivity patterns of benzo-fused 1,3,2-dithiaphospholes, which are closely related to N-heterocyclic phospholenes (NHPs) by replacement of NR by S. Finally we provide a comparative study of these dithiaphospholes with their isolobal dioxaphosphole and diazaphosphole counterparts as pre-catalysts for the hydroboration of aldehydes with pinacolborane.

\section{Results and discussion}

\section{Synthesis}

$P$-Halo-benzodithiaphospholes were prepared by Baudler ${ }^{23}$ in 1973 who showed that reduction led to P-P coupling to form the $\sigma$-bonded dimers 4 and $\mathbf{5}$ (Scheme 2). Burford showed that treatment of these $P$-halo dithiaphospholes with Lewis acids $\left(\mathrm{AlCl}_{3}\right.$ or $\left.\mathrm{GaCl}_{3}\right)$ forms the corresponding dithiaphosphenium salts (Scheme 2). ${ }^{24-26}$ In our study, the syntheses of 1a-1c and 2a-2c essentially followed the protocols first described by Baudler (Scheme 2) via the addition of either toluene-3,4-

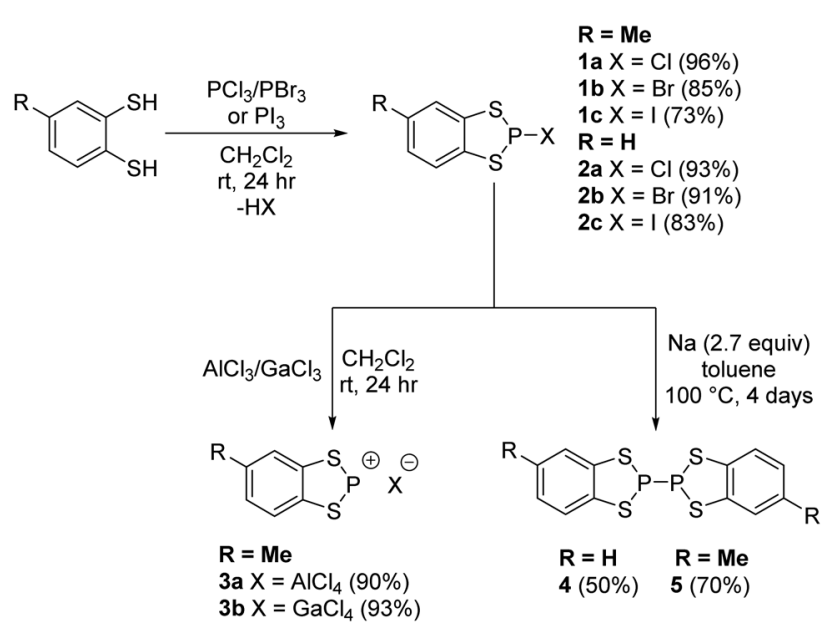

Scheme 2 Synthesis of dithiaphosphole derivatives. dithiol or benzene dithiol to the appropriate phosphorus trihalide, $\mathrm{PX}_{3}$, under ambient conditions with the derivatives 1a-2c recovered in very good to excellent yields (73-96\%).

\section{${ }^{31} \mathbf{P}$ chemical shift}

The dithiaphospholes were initially characterised by in $s i t u{ }^{31} \mathrm{P}$ $\left\{{ }^{1} \mathrm{H}\right\}$ NMR spectroscopy, which revealed a singlet resonance centred at $\delta=160.4,163.3$, or $155.0 \mathrm{ppm}$ for 1a-1c respectively and complete consumption of the $\mathrm{PX}_{3}$ starting material ( $c a . \delta=$ 219, 227 and 178 ppm for $\mathrm{PCl}_{3}, \mathrm{PBr}_{3}$ and $\mathrm{PI}_{3}$ respectively). The shielding constant $\sigma$ can be broken down into diamagnetic shielding $\left(\sigma_{\mathrm{d}}\right)$ and paramagnetic shielding $\left(\sigma_{\mathrm{p}}\right)$ contributions. For ${ }^{1} \mathrm{H}$ NMR spectroscopy the chemical shift is dominated by the diamagnetic shielding which is related to the electron density and hence sensitive to the electron-withdrawing/releasing nature of substituents attached to the ${ }^{1} \mathrm{H}$ nucleus. Conversely, for other nuclei, paramagnetic shielding is significant. The paramagnetic shielding arises from mixing of the ground state wavefunction with excited state wavefunctions and is therefore closely related to the energy of low-lying states where oxidation state and coordination geometry play an important role. For a series of structurally closely-related complexes such as phosphines empirical correlations can be made. For tertiary phosphines, $\mathrm{PR}_{3}$, the chemical shift follows $\delta_{\mathrm{P}}=-62+\sum \sigma_{\mathrm{R}}$ where $\sigma_{\mathrm{R}}$ is a constant for a specific R group. ${ }^{27}$ The additive nature of the chemical shielding effects for different groups can therefore be used in a chemically meaningful way. For example, the ${ }^{31} \mathrm{P}$ NMR data for 1a-1c (Table 1) do not follow a simple trend based on electronegativity arguments but do correlate with a similar trend observed for $\mathrm{PX}_{3}$. From the reported ${ }^{31} \mathrm{P} \mathrm{NMR}$ data for $\mathrm{PX}_{3}\left(\mathrm{X}=\mathrm{Cl}, \mathrm{Br}, \mathrm{I}, \mathrm{NMe}_{2}\right.$, OMe, SMe and $\mathrm{Ph}$ ), $\sigma_{\mathrm{R}}$ values can be derived (Table 1) and chemical shifts estimated based on the chemical environment of the phosphine (Table 1). While imperfect the correlation coefficient (0.85) is good, especially given the approximation that the $\mathrm{RC}_{6} \mathrm{H}_{3} \mathrm{~S}_{2}$ unit can be approximated by two SMe groups.

\section{Crystal structures of $1 \mathrm{a}-1 \mathrm{c}$ and $2 \mathrm{a}-2 \mathrm{c}$}

Crystals of these compounds were obtained by reducing the volume of the crude reaction mixture to form a (super)saturated $\mathrm{CH}_{2} \mathrm{Cl}_{2}$ solution and then cooling to $-40{ }^{\circ} \mathrm{C}$. Crystals

Table $1{ }^{31} \mathrm{P}$ NMR spectroscopy analysis

\begin{tabular}{lllll}
\hline $\mathrm{X}$ & $\mathrm{F}$ & $\mathrm{Cl}$ & $\mathrm{Br}$ & $\mathrm{I}$ \\
\hline${ }_{\mathrm{K}}$ & 53.3 & 94 & 96.3 & 80 \\
${ }^{31} \mathrm{P} \delta_{\text {calc }}$ for $(\mathrm{MeS})_{2} \mathrm{PX}$ & 116.3 & 157 & 159 & 143 \\
${ }^{31} \mathrm{P} \delta_{\text {obs }}$ for [1]X & - & 161.4 & 163.6 & 155.4 \\
\hline $\mathrm{X}$ & $\mathrm{OMe}$ & $\mathrm{NMe}_{2}$ & $\mathrm{SMe}$ & $\mathrm{Ph}$ \\
\hline${ }^{{ }^{3} \mathrm{P}} \delta_{\text {calc }}$ for [1]X & 67.3 & 61.5 & 62.5 & 18.7 \\
${ }^{31} \mathrm{P} \delta_{\text {obs }}$ for [1]X & 130.3 & 124.5 & 125.5 & 81.7 \\
${ }^{a} \mathrm{For}[\mathbf{1}] \mathrm{OCH}_{2} \mathrm{Ph}$ (this & $124.5^{a}$ & $94.4^{b}$ & $113^{c}$ & \\
$\mathrm{C}_{6} \mathrm{H}_{4}(\mathrm{~S}-1)_{2}$ this work. & ${ }^{b}$ For & {$[\mathbf{1}] \mathrm{N}\left(\mathrm{SiMe}_{3}\right)_{2}$} & (this work). & ${ }^{c}$ For \\
\end{tabular}



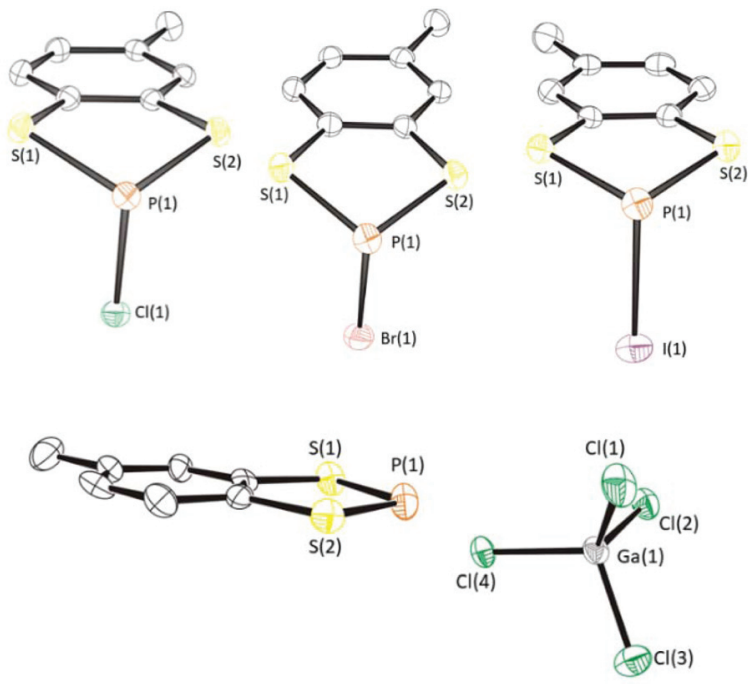

Fig. 1 (Top) Solid-state structures of $1 \mathrm{a}-1 \mathrm{c}$ (top left to right respectively), (Bottom) crystal structure of $\mathbf{3 b}$. Thermal ellipsoids drawn at 50\% probability and $\mathrm{H}$-atoms removed for clarity.

typically formed over 18-36 h. Compounds 1a-1c were found to crystallise in the monoclinic space group $P 2_{1} / c$ with one molecule in the asymmetric unit. Compound 2a crystallises in the monoclinic space group $P 2_{1} / n$ while $2 \mathbf{b}$ and $2 \mathbf{c}$ crystallise in the triclinic space group $P \overline{1}$ with two molecules in the asymmetric unit. Structure determination of $\mathbf{1 a - 1 c}$ revealed the expected three-coordinate phosphorus centre with an exocyclic $\mathrm{P}-\mathrm{X}(\mathrm{X}=\mathrm{Cl}, \mathrm{Br}$, or $\mathrm{I})$ bond (Fig. 1). The dithiaphosphole ring is non-planar with a distinct envelope geometry associated with a folding about the $S \cdots S$ vector. On descending group 17, there is a decrease in the fold angle $\theta$ (defined as the angle formed between $\mathrm{S}_{2} \mathrm{P}$ and $\mathrm{C}_{2} \mathrm{~S}_{2}$ planes) and a move towards molecular planarity. The fold angle $(\theta)$ varies from of $26.06^{\circ}(\mathrm{X}=\mathrm{Cl})$ to $24.27^{\circ}(\mathrm{X}=\mathrm{Br})$ and $19.62^{\circ}(\mathrm{X}=\mathrm{I})$. Within the series 1a-1c an elongation of the $\mathrm{P}-\mathrm{X}$ bond is observed in relation to a conventional P-X bond. The bond lengths are 2.1134(7) $\AA$ (1a),

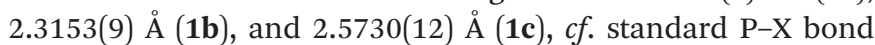
lengths of $2.008 \AA$ ( $\mathrm{P}-\mathrm{Cl}), 2.206 \AA$ ( $\mathrm{P}-\mathrm{Br})$ and 2.490-2.493 $(\mathrm{P}-\mathrm{I}){ }^{28}$ Similar features were found for $2 \mathrm{a}-2 \mathbf{c}$. The symmetry breaking generated by the presence of the methyl group leads to chirality at the $\mathrm{P}$ centre. However, the presence of an inversion centre in all these structures leads to structures containing $50: 50$ mixtures of both enantiomers.

\section{Computational studies of $1 \mathrm{a}-1 \mathrm{c}$}

To understand better the structure and bonding in these dithiaphosphole compounds, we turned to computational methods. Natural Bond Order (NBO) analysis (M06-2X and 6-311+G(2d,p)) was performed on 1a-1c (Table 2 and ESI + ), which for 1a revealed a Wiberg $\mathrm{P}-\mathrm{Cl}$ bond order of 0.86 . This reduced bond order can be explained by hyperconjugation between the $\pi$ electrons in the $\mathrm{C}_{2} \mathrm{~S}_{2}$ unit and the $\sigma^{*}(\mathrm{P}-\mathrm{X})$ orbital, in turn weakening the $\mathrm{P}-\mathrm{X}$ bond, which is consistent with observations we have previously reported on related diaza-
Table 2 DFT analysis of compounds $1 \mathrm{a}-1 \mathrm{c}$ and 3 (cation)

\begin{tabular}{lllll}
\hline & 1a & 1b & 1c & 3 \\
\hline P-X bond order & 0.86 & 0.87 & 0.90 & N/A \\
P partial charge & +0.53 & +0.46 & +0.36 & +0.53 \\
X partial charge $^{a}$ & -0.32 & -0.27 & -0.17 & N/A \\
S partial charge $^{a}$ & +0.06 & +0.07 & +0.07 & +0.30
\end{tabular}

All computations used the M06-2X functional and 6-311G+(2d,p) basis set for all atoms except the I atom in 1c, for which the basis set Def2TZVP was implemented. ${ }^{a}$ Average value of the two $\mathrm{S}$ atoms taken.

phosphole compounds. $^{29}$ In addition, NBO analysis showed significant polarisation in this bond, with a natural charge of +0.53 on the $\mathrm{P}$ heteroatom, and -0.33 on the $\mathrm{Cl}$ atom; the $S$ atoms exhibit natural charges of +0.06 . Comparing the results of $\mathbf{1 a}$ to $\mathbf{1 b}$ and $\mathbf{1 c}$, a reduction in the polarisation of the $\mathrm{P}-\mathrm{X}$ bond was found to be accompanied by a small increase in bond order. A similar NBO analysis on the cation in $\mathbf{3 b}$ (vide infra) was performed which showed a bond order of 1.35 and 1.37 for the $\mathrm{P}-\mathrm{S}$ bonds and partial charges of +0.53 and +0.30 at $\mathrm{P}$ and $\mathrm{S}$ respectively.

\section{Reaction with Lewis acids}

Stoichiometric treatment of $\mathbf{1 a}$ with the Lewis acids $\mathrm{AlCl}_{3}$ and $\mathrm{GaCl}_{3}$ generated the corresponding phosphenium salts $\mathbf{3 a}$ and 3b respectively in excellent yield (90-93\%) as highly air-sensitive crystalline solids. The solid-state structure of $\mathbf{3 a}$ has previously been reported by Cameron and Linden. ${ }^{30}$ Compound 3b was found to crystallise in the monoclinic space group $P 2_{1} / c$ with one molecule in the asymmetric unit. As with the previously determined structure of $\mathbf{3 a}$, the solid-state structure of 3b exhibits a planar $\mathrm{C}_{2} \mathrm{~S}_{2} \mathrm{P}$ ring and notably shorter $\mathrm{P}-\mathrm{S}$ bonds

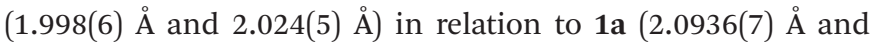
2.0954(7) $\AA$ ), consistent with $3 \mathrm{p}-3 \mathrm{p} \pi$ conjugation and some delocalisation within the formally $10 \pi$ aromatic benzodithiaphosphenium cation. This $\pi$-conjugated perspective is supported through the computational studies described above where the P-S bond orders are 1.33 and 1.35 in the cation. The closest cation-anion contact in $\mathbf{3 b}$ is a $\mathrm{P} \cdots \mathrm{Cl}$ contact at $3.317(5) \AA$, which is well within the sum of the van der Waals radii $(3.55 \AA)$.

\section{Reduction}

Reduction of the chloride salt 1a has previously been achieved using sodium metal to form $4^{23}$ However we found that the rate of reduction of both $1 \mathbf{a}$ and $2 \mathbf{a}$ was particularly sensitive to the size of the sodium pieces employed. Initial studies required two to four days to ensure complete reduction (monitored by ${ }^{31} \mathrm{P}$ NMR spectroscopy) but initial pre-treatment of a suspension of small pieces of sodium metal in toluene $\left(100{ }^{\circ} \mathrm{C}, 20 \mathrm{~min}\right)$ afforded a fine sodium dispersion which led to shorter reaction times ( $c a$. two days). The P-P coupled product 5 exhibits a diagnostic ${ }^{31} \mathrm{P}$ chemical shift at +40.6 ppm, significantly upfield in relation to the $\mathrm{P}(\mathrm{III})$ derivatives 1a and $\mathbf{2 a}$ and comparable with $\left[(\mathrm{MeO})_{2} \mathrm{C}_{6} \mathrm{H}_{2} \mathrm{~S}_{2} \mathrm{P}\right]_{2}(\delta=$ 
$50 \mathrm{ppm}){ }^{31}$ The methyl group can give rise to different diastereoisomers but a careful examination of the ${ }^{31} \mathrm{P}$ NMR data failed to provide unambiguous evidence for the presence of both diastereomers. However the presence of two diastereomers could explain the inability, despite multiple attempts, to grow good quality crystals of $\mathbf{5}$, which is in contrast to 4 .

During the reduction process an intermediate was observed at approximately $113 \mathrm{ppm}$ which is tentatively attributed to a dithiolate bridged intermediate (Fig. 2). Evidence for the nature of this intermediate comprises good agreement of the observed chemical shift with the closely related dialkoxybenzoderivatives $(\delta=115-120 \mathrm{ppm}),{ }^{15}$ as well as comparative reduction chemistry of $P$-chloro-diazaphospholes using $\mathrm{Na}(\mathrm{K}) .^{32-34}$

Compounds $\mathbf{4}$ and $\mathbf{5}$ were isolated by filtration to remove insolubles and dried in vacuo to afford yellow solids which, upon slow evaporation of a saturated toluene solution, afforded a polycrystalline mass. In the case of $\mathbf{4}$ small crystals suitable for X-ray diffraction were cut from the bulk sample. While all samples studied exhibited persistent twinning, a satisfactory solution could be determined in the monoclinic space group $P 2_{1} / n$ with half a molecule in the asymmetric unit with the structure of $\mathbf{4}$ located about an inversion centre midway along the P-P bond (Fig. 3). The P-P bond length (2.233(2) $\AA$ ) is comparable with that observed in the two other crystallographically determined systems containing $\mathrm{S}_{2} \mathrm{P}-\mathrm{PS}_{2}$ sub-units; the one previously structurally characterised dithiaphosphole, ${ }^{31} \quad\left[(\mathrm{MeO})_{2} \mathrm{C}_{6} \mathrm{H}_{2} \mathrm{~S}_{2} \mathrm{P}\right]_{2}$ at $2.2350(16) \AA$ and the binaphtho[1,8-de][1,3,2]dithiaphosphinine reported by Woollins at $2.2306(13) \AA^{35}$ It should be noted that there appears to be a strong preference for dimerisation via localised $\mathrm{P}-\mathrm{P} \sigma$-bond formation in these systems whereas the lighter $\mathrm{N}$-atom dithiazolyl analogues dimerise via multi-centre $\pi-\pi$ interactions. This is likely a result of the superior strength of
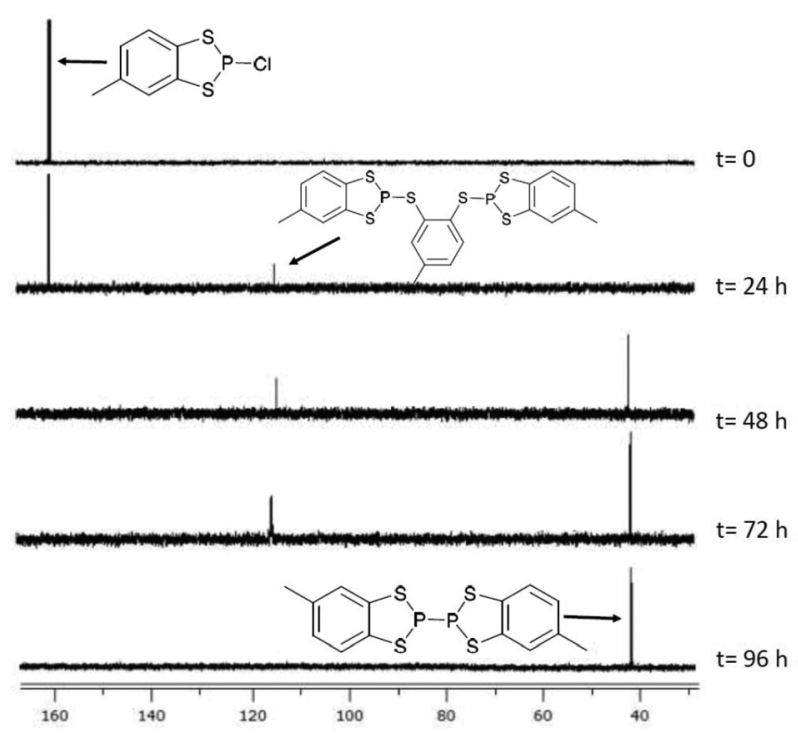

Fig. 2 In situ ${ }^{31} \mathrm{P}\left\{{ }^{1} \mathrm{H}\right\}$ NMR of the reduction of $1 \mathrm{a}$ with $\mathrm{Na}$ metal in toluene to form 5 .

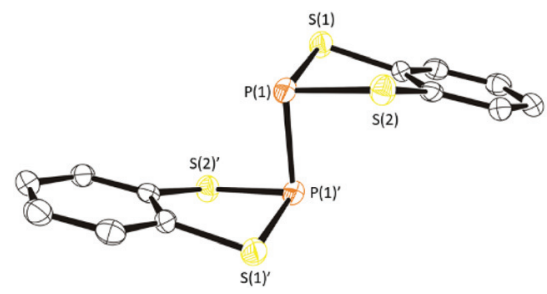

Fig. 3 Solid-state structure of 4 . Thermal ellipsoids drawn at $50 \%$ probability and $\mathrm{H}$-atoms removed for clarity.

the $\mathrm{P}-\mathrm{P}$ single bond ( $201 \mathrm{~kJ} \mathrm{~mol}^{-1}$ ) in relation to the $\mathrm{N}-\mathrm{N}$ bond (167 $\mathrm{kJ} \mathrm{mol}^{-1}$ ) coupled with stronger $2 \mathrm{p}-3 \mathrm{p} \mathrm{N}-\mathrm{S} \pi$-bonding in DTAs in relation to $3 \mathrm{p}-3 \mathrm{p} \mathrm{P}-\mathrm{S} \pi$-bonding in $\mathbf{4}$, i.e. the loss in $\pi$-bonding is more than compensated by formation of a localised $2 \mathrm{c}, 2 \mathrm{e}^{-}$bond for $\mathbf{4}$ and $5 .^{36}$ The structure of $\mathbf{4}$ also exhibits a folding of the $\mathrm{C}_{2} \mathrm{~S}_{2} \mathrm{P}$ heterocycle about the $\mathrm{S} \cdots \mathrm{S}$ vector with a fold angle of $33.01^{\circ}$, slightly greater than in 1a-1c (26.06-19.62 $2^{\circ}$ vide supra) and $2 \mathbf{a}\left(28.35^{\circ}\right.$, see ESI + ).

Variable temperature solution EPR studies on $\mathbf{4}$ and $\mathbf{5}$ showed no tendency for homolytic bond cleavage to form radicals up to $110^{\circ} \mathrm{C}$. This is in contrast to the isolobal diazaphospholes, containing the $\mathrm{C}_{2}(\mathrm{NR})_{2} \mathrm{P}$ ring system, which generate radicals upon warming through $\mathrm{P}-\mathrm{P}$ bond cleavage. ${ }^{37-41}$ The difference is likely due to the steric demands of the $\mathrm{N}-\mathrm{R}$ group. On the other hand, the $\mathrm{P}-\mathrm{P}$ bond could be oxidatively cleaved with $\mathrm{SO}_{2} \mathrm{Cl}_{2}, \mathrm{Br}_{2}$ and $\mathrm{I}_{2}$ reforming $1 \mathrm{a}-1 \mathrm{c}$ based on ${ }^{31} \mathrm{P}$ NMR spectroscopy studies and preparative scale reactions.

\section{Substitution chemistry on 1a}

Reaction of 1a with $\mathrm{Li}\left[\mathrm{N}\left(\mathrm{SiMe}_{3}\right)_{2}\right]$ in a 1:1 mole ratio in toluene afforded 1d (Scheme 3 ) as a colourless oil which was characterised by multinuclear NMR spectroscopy. The ${ }^{31} \mathrm{P}$ NMR chemical shift for 1d (+94.9 ppm) is a little lower than that predicted based on the additive shielding approach (Table 1) but may reflect the electronic and steric dissimilarity between $\mathrm{NMe}_{2}$ and $\mathrm{N}\left(\mathrm{SiMe}_{3}\right)_{2}$. Condensation of $\mathbf{1 d}$ with two further equivalents of 1a proved sensitive to the solvent employed but reflux in MeCN for $18 \mathrm{~h}$ afforded the tri-functionalised product 1e $\left({ }^{31} \mathrm{P}\right.$ NMR, $\left.\delta=86.8 \mathrm{ppm}\right)$ as a white solid $(87 \%)$ which was recrystallised by cooling a saturated $\mathrm{CH}_{2} \mathrm{Cl}_{2}$ solution to $-20^{\circ} \mathrm{C}$. Compound $1 \mathrm{e}$ crystallised in the rhombo-

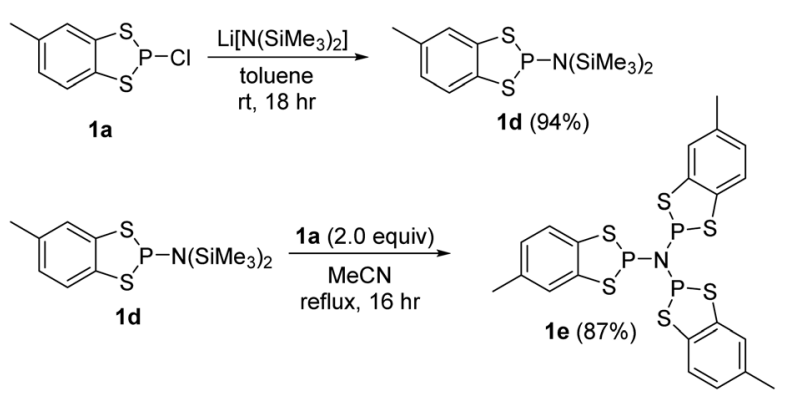

Scheme 3 Synthesis of $1 d$ and 1 e. 


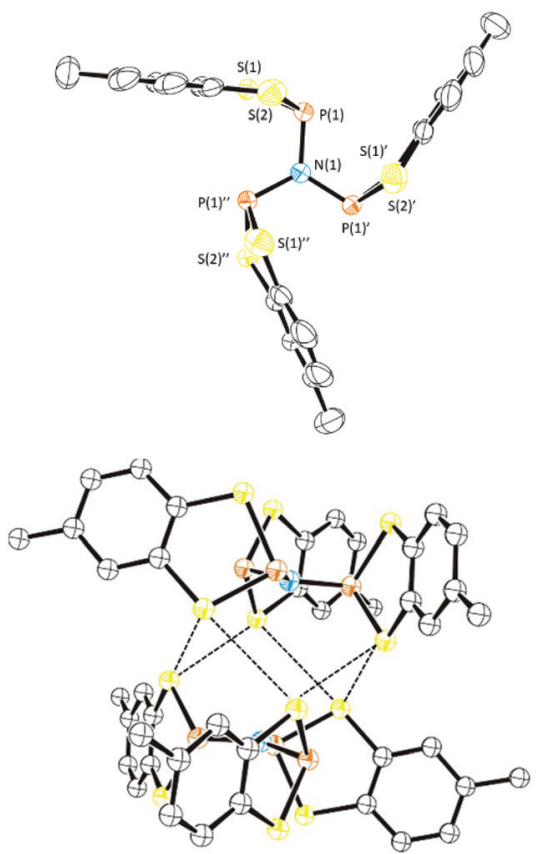

Fig. 4 Molecular structure of 1e (Top) and supramolecular dimer linked via S...S contacts (Bottom).

hedral space group $P \overline{3}$ (Fig. 4) with the $\mathrm{N}$ atom on the threefold axis and a third of a molecule in the asymmetric unit. The five-membered $\mathrm{C}_{2} \mathrm{~S}_{2} \mathrm{P}$ ring in 1e again adopts an envelope geometry with a fold angle of $20.66^{\circ}$. The $\mathrm{P}-\mathrm{S}$ bond lengths in $1 \mathrm{e}$ are 2.105(2) and 2.125(2) $\AA$ and the exocyclic $\mathrm{P}-\mathrm{N}$ bond length (1.7274(2) $\AA$ ) falls in the normal range for $\mathrm{P}-\mathrm{N}$ single bonds (1.70-1.77 $\AA$ ). The PNP bond angle $\left(119.8^{\circ}\right)$ is very close to that expected for an $\mathrm{sp}^{2}-\mathrm{N}$ suggesting a lone pair of $\mathrm{p}$-character. The structure of $\mathbf{1 e}$ is analogous to the previously reported dithia-arsole, $\left(\mathrm{MeC}_{6} \mathrm{H}_{3} \mathrm{~S}_{2} \mathrm{As}\right)_{3} \mathrm{~N}{ }^{21}$ Molecules of 1e aggregate through a series of six symmetry-equivalent $\mathrm{S} \cdots \mathrm{S}$ contacts at $3.512 \AA$, marginally shorter than the sum of the van der Waals radii $(3.60 \AA)$. These contacts generate a supramolecular " $\mathrm{S}_{6}$ " chair motif (Fig. 4).

\section{Lewis acidity studies on $3 \mathbf{b}$}

The phosphenium salts $\mathbf{3} \mathbf{a}$ and $\mathbf{3 b}$ are extremely air sensitive in solution and particularly prone to hydrolysis reflected in a diagnostic doublet in the ${ }^{31} \mathrm{P}$ NMR spectrum $(\delta=57.2 \mathrm{ppm}$, ${ }^{1} J_{\mathrm{PH}}=699 \mathrm{~Hz}$ ) which collapses to a singlet in the ${ }^{31} \mathrm{P}\left\{{ }^{1} \mathrm{H}\right\} \mathrm{NMR}$ spectrum. Prior work by Burford reported ${ }^{26}$ the ${ }^{31} \mathrm{P}$ chemical shift for these cations around $410 \mathrm{ppm}$ but indicated it was sensitive to both temperature and concentration. They proposed the presence of aggregated species such as $\left[\left(\mathrm{C}_{6} \mathrm{H}_{4} \mathrm{~S}_{2} \mathrm{P}\right)_{2} \mathrm{Cl}\right]^{+}$(formed by disproportionation of $2 \mathrm{MCl}_{4}{ }^{-}$to form $\mathrm{Cl}^{-}$and $\mathrm{M}_{2} \mathrm{Cl}_{7}^{-}$) in equilibrium with $\left[\mathrm{C}_{6} \mathrm{H}_{4} \mathrm{~S}_{2} \mathrm{P}^{+}\right]$:

$$
2\left[\mathrm{C}_{6} \mathrm{H}_{4} \mathrm{~S}_{2} \mathrm{P}\right]\left[\mathrm{MCl}_{4}\right] \rightleftarrows\left[\left(\mathrm{C}_{6} \mathrm{H}_{4} \mathrm{~S}_{2} \mathrm{P}\right)_{2} \mathrm{Cl}\right]\left[\mathrm{M}_{2} \mathrm{Cl}_{7}\right] \text {. }
$$

In this context Russell's work on the related phosphenium ion $\left\{(\mathrm{RC})_{4} \mathrm{P}\right\}^{+}$led to isolation of the $\left[\left\{(\mathrm{RC})_{4} \mathrm{P}\right\}_{2} \mathrm{Cl}\right]^{+}$cation. ${ }^{42}$ Despite the uncertainty in the exact nature of the active species present in solution, it exhibits some Lewis acid character, based on in situ ${ }^{31} \mathrm{P}$ NMR data. For example addition of $\mathrm{Ph}_{3} \mathrm{P}$ afforded two doublets $\left(\delta=52 \mathrm{ppm},{ }^{1} J_{\mathrm{PP}}=444 \mathrm{~Hz} ; \delta=\right.$ $8 \mathrm{ppm},{ }^{1} J_{\mathrm{PH}}=444 \mathrm{~Hz}$ ) whereas addition of $\mathrm{Ph}_{3}$ As afforded a singlet at $47 \mathrm{ppm}$. When initially working with the cationic phosphenium $\mathbf{3 b}$ in THF, a chemical shift in the ${ }^{31} \mathrm{P}$ NMR spectrum at $\delta=124 \mathrm{ppm}$ was observed, which more closely resembles a three-coordinate $\mathrm{P}(\mathrm{III})$-centre $\left(c f . \quad 1 \mathrm{a}{ }^{31} \mathrm{P} \delta=\right.$ $160 \mathrm{ppm})$. Indeed, the chemical shift is in agreement with an O-bound $\mathrm{S}_{2} \mathrm{P}-\mathrm{O}$ centre (expected around $130 \mathrm{ppm}$, Table 1). It was also found that, while visually monitoring the reaction, the THF solution became viscous over one hour and ${ }^{1} \mathrm{H}$ NMR spectra analysis showed the rapid formation of poly(THF) at ambient temperature. Indeed, under more controlled conditions using 0.15 mol\% $3 \mathbf{b}$, 80\% conversion of THF into poly (THF) occurred in 24 hours, with the reaction rate slowing over time due to the increasing viscosity from the formation of poly (THF). The polymerisation of THF is a facile process and follows the well-known cationic ring opening polymerisation (CROP) mechanism, in which $\mathbf{3 b}$ acts as the cationic initiator. ${ }^{43}$ It should be noted that stirred solutions of (i) $\mathrm{GaCl}_{3}$ with THF and (ii) 1a with THF gave no polymer formation, confirming the role of the phosphenium cation in the polymerisation process. An end group analysis (integral of the terminal $\mathrm{CH}_{3}$ group of the cationic initiator to the $\mathrm{CH}_{2}$ group of the poly(THF) permitted number average molecular weights $\left(M_{\mathrm{n}}\right)$ to be determined which fell in the range 1897-3163, corresponding to $23<n<41$ THF units (see ESI $\$$ ). Interestingly, when attempting to use $\mathbf{3 a}$ for CROP no formation of poly (THF) occurred. In this case ${ }^{31} \mathrm{P}$ NMR studies revealed a singlet ( $\delta=+161 \mathrm{ppm}$ ) which is believed to be due to reformation of 1a and formation of the adduct THF. $\mathrm{AlCl}_{3}$. Similar degradation of the counterion has also been observed for the tetraphenylborate salt which was shown to form $\mathrm{MeC}_{6} \mathrm{H}_{3} \mathrm{~S}_{2} \mathrm{P}-\mathrm{Ph}$ and $\mathrm{Ph}_{3} \mathrm{~B}$, reflecting the high Lewis acidity of the $\mathrm{P}^{+}$centre. ${ }^{26}$ Attempts to polymerise propylene oxide or 1,4-dioxane with $\mathbf{3 b}$ under the same conditions afforded a similar downfield shift $\left({ }^{31} \mathrm{P} \delta=127\right.$ and $125 \mathrm{ppm}$ respectively) to that observed in THF, consistent with adduct formation but there was no evidence for polymerisation of either of these substrates.

\section{Reduction catalysis}

In the last few years phospholes, diazaphospholenes and their derivatives have received attention in catalytic reduction chemistry by a number of different groups, including ourselves. ${ }^{15,22,44,45}$ We therefore looked to see whether these dithiaphospholes and their derivatives would be active in the reduction of aldehydes with pinacolborane (HBpin). To investigate this, we initially synthesised a library of potential pre-catalysts. Previously the groups of Kinjo and Speed have demonstrated that the use of benzyloxy (Bn) and neopentyloxy (Np) substituted phosphorus systems are effective in reduction catalysis. $^{15,44,45}$ In this context, the alkoxy derivatives $\mathbf{6 a}$ and 6b were prepared by reaction of the dithiaphosphole 1a with either benzyl alcohol or neopentyl alcohol in the presence of base, affording compounds $\mathbf{6 a}$ and $\mathbf{6 b}$ in moderate yield 


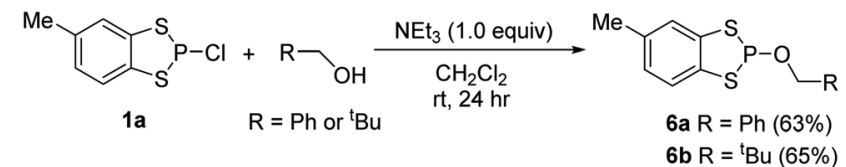

Scheme 4 Synthesis of dithiaphosphole pre-catalysts bearing a benzyloxy or neopentyloxy group.

(63-65\%) (Scheme 4). These compounds show upfield signals in the ${ }^{31} \mathrm{P}$ NMR spectrum compared to precursor $1 \mathrm{a}$, with ${ }^{31} \mathrm{P}$ resonances at $\delta=124.5$ and $123.6 \mathrm{ppm}$ for $\mathbf{6 a}$ and $\mathbf{6 b}$ correspondingly, in agreement with the computed change in their chemical shift (Table 1). This methodology was also extended to synthesise dioxaphosphole and diazaphosphole pre-catalysts, providing an opportunity to compare the relative catalytic activity of this isolobal series of $\mathrm{C}_{2} \mathrm{E}_{2} \mathrm{P}(\mathrm{E}=\mathrm{O}, \mathrm{NR}, \mathrm{S})$ heterocycles (Scheme 5). To synthesise these compounds, the chloride and bromide pre-cursors were first produced. In the case of the dioxaphospholes, catechol was reacted with phosphorus(III) chloride or phosphorus(III) bromide and triethyl amine to yield $7 \mathbf{a}$ and $7 \mathbf{b}$ in $36 \%$ and $41 \%$ yield respectively, whose corresponding ${ }^{31} \mathrm{P}$ NMR chemical shifts are $\delta=173.6$ and $195.3 \mathrm{ppm}$. In analogous fashion, reaction of $7 \mathrm{a}$ with either benzyl alcohol or neopentyl alcohol afforded 9a and 9b (68\% and 64\% yield) with upfield ${ }^{31} \mathrm{P}$ NMR chemical shifts of $\delta$ $=126.9$ and 127.4 ppm respectively. Although the same procedure was attempted for the diazaphosphole compound $\mathbf{8 a}$, addition of benzyl alcohol or neopentyl alcohol gave a mixture of three species in the ${ }^{31} \mathrm{P}$ NMR spectrum, only one of which was the desired product (the others are believed to arise from hydrolysis). Nevertheless, abstraction of the chloride from $\mathbf{8 a}$ with TMSOTf to produce the cationic phosphenium $\mathbf{1 0}$ was performed successfully.

With a range of pre-catalysts in hand, an initial screening test was conducted in order to see which of these compounds was the most active in the reductive catalytic hydroboration of aldehydes. Therefore, $10 \mathrm{~mol} \%$ of compounds 1, 3, 6, 7, 8, 9 and 10 were added to 4-(trifluoromethyl)benzaldehyde and

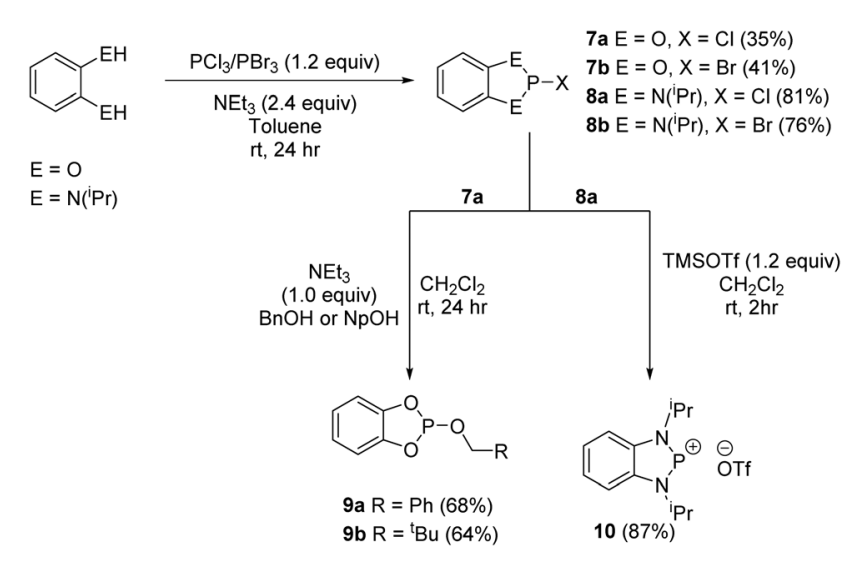

Scheme 5 Synthesis of dioxaphosphole and diazaphosphole compounds.
Table 3 Pre-catalyst screening results

\begin{tabular}{|c|c|c|c|}
\hline \multirow[b]{2}{*}{ Entry } & \multicolumn{2}{|c|}{$\begin{array}{c}\text { HBpin (1.0 equiv) } \\
10 \mathrm{~mol}^{2} \text { cat. } \\
\mathrm{CDCl}_{3}, \mathrm{rt}\end{array}$} & \multirow{2}{*}{ Conversion $^{a}(\%)$} \\
\hline & Pre-catalyst & Time (h) & \\
\hline 1 & None & 24 & $<5$ \\
\hline 2 & $1 \mathrm{a}$ & 24 & $<5$ \\
\hline 3 & $1 b$ & 24 & 14 \\
\hline 4 & $1 \mathrm{c}$ & 24 & 61 \\
\hline 5 & $3 \mathbf{a}$ & 12 & $>95$ \\
\hline 6 & $3 \mathbf{b}$ & 12 & $>95$ \\
\hline 7 & $6 a$ & 24 & 9 \\
\hline 8 & $6 b$ & 24 & 8 \\
\hline 9 & $7 \mathbf{a}$ & 24 & $<5$ \\
\hline 10 & $7 \mathbf{b}$ & 24 & $<5$ \\
\hline 11 & $8 a$ & 24 & $<5$ \\
\hline 12 & $8 b$ & 24 & $<5$ \\
\hline 13 & $9 a$ & 24 & 30 \\
\hline 14 & $9 b$ & 24 & 35 \\
\hline 15 & 10 & 6 & $>95$ \\
\hline 16 & TMSOTf & 24 & 56 \\
\hline 17 & $\mathbf{A l C l}_{3}$ & 24 & 68 \\
\hline
\end{tabular}

${ }^{a}$ Conversion measured by in situ ${ }^{1} \mathrm{H}$ NMR spectroscopy.

HBpin in $\mathrm{CDCl}_{3}$. The conversion was then monitored by both ${ }^{1} \mathrm{H}$ and ${ }^{19} \mathrm{~F}$ NMR spectroscopy at 2-, 6-, 12- and 24-hour intervals. Table 3 shows the results of the pre-catalyst screening. The dithiaphosphole 1a was found to be catalytically inactive, with $<5 \%$ conversion observed in the ${ }^{1} \mathrm{H}$ NMR spectrum after 24 hours. A mild improvement was found using 1b, with 14\% conversion detected after 24 hours. More interestingly though was the use of 1c, which gave $61 \%$ product conversion to 11 a after 24 hours. The differences in performance of 1a-1c can be attributed to the varying electronic properties of the structures, as found by NBO analysis (vide supra) and correlate with the $\mathrm{P}-\mathrm{X}$ bond energy. Noteworthy, when using the benzyloxy and neopentyloxy derived dithiaphospholes $\mathbf{6 a}$ and $\mathbf{6 b}$, the catalytic performance fared little better than their chloride precursor, with just $9 \%$ and $8 \%$ conversion to 11a after 24 hours respectively (see ESI for NBO analysis). In addition to this, the catalytic ability of the phosphenium cations $\mathbf{3 a}$ and $\mathbf{3} \mathbf{b}$ were examined. Both $\mathbf{3} \mathbf{a}$ and $\mathbf{3} \mathbf{b}$ afforded quantitative conversion to the hydroborated product 11a in 12 hours. However, knowing that it was possible for dynamic exchange to occur in solution between one of the chlorides on $\mathrm{AlCl}_{4}{ }^{-}$and the phosphorus centre to reform $1 \mathrm{a}$ and give free $\mathrm{AlCl}_{3}$ (vide supra), a control reaction was undertaken in which $10 \mathrm{~mol} \% \mathrm{AlCl}_{3}$ was used as the pre-catalyst for the hydroboration catalysis. Using $\mathrm{AlCl}_{3},{ }^{1} \mathrm{H}$ NMR spectroscopy showed that after 24 hours only $68 \%$ conversion to 11a had occurred. This therefore showed that the phosphenium species were indeed responsible for attaining quantitative conversion of 4-(trifluoromethyl)benzaldehyde to 11a.

The dioxaphosphole pre-catalysts, $7 \mathbf{a}$ and $\mathbf{7 b}$ showed little conversion to the hydroborated product, with $<5 \%$ conversion after 24 hours. However, employing $\mathbf{9 a}$ and $\mathbf{9 b}$ showed a slight improvement on these results in relation to the sulfur deriva- 
tives, giving $30 \%$ and $35 \%$ conversion to 11 a respectively after 24 hours. Given the low conversion results for these pre-catalysts, alternative solvents were explored and the catalysis experiments repeated in both toluene and acetonitrile. Neither afforded appreciable improvements in conversion after 24 hours. In a similar theme, the diazaphosphole compounds $\mathbf{8 a}$ and $\mathbf{8 b}$ were found to be inactive for the catalysis. Significantly $10 \mathrm{~mol} \%$ of the cationic phosphenium $\mathbf{1 0}$ was found to be highly active, giving quantitative conversion to 11a in 6 hours, as revealed by ${ }^{1} \mathrm{H}$ NMR spectroscopy. As a control reaction, the use of TMSOTf was used as a potential pre-catalyst. Analysis of both the ${ }^{1} \mathrm{H}$ and ${ }^{19} \mathrm{~F}$ NMR spectra revealed that $56 \%$ conversion was achieved after 24 hours; with multiple products observed.

Having discovered that the phosphenium triflate $\mathbf{1 0}$ was clearly the most active pre-catalyst, reaction conditions were optimised by first assessing the performance of a range of solvents, while maintaining the catalytic loading of $\mathbf{1 0}$ at $10 \mathrm{~mol} \%$. The data are summarised in Table 4. Both $\mathrm{CH}_{2} \mathrm{Cl}_{2}$ and $\mathrm{CDCl}_{3}$ gave quantitative conversion to the hydroborated product 11a, with the latter occurring at a faster rate than the former. Use of either THF or MeCN failed to give quantitative conversion after 24 hours. In addition, use of toluene as a solvent was attempted but $\mathbf{1 0}$ proved sparingly soluble. As $\mathrm{CDCl}_{3}$ proved to be the most effective solvent, the reaction conditions were further optimised. Increasing the equivalence of HBpin to two as opposed to one made little difference to the reaction, with both giving $>95 \%$ conversion within six hours. Moving from $10 \mathrm{~mol} \%$ to $5 \mathrm{~mol} \%$ gave quantitative yields although the rate of product conversion was reduced, with the reaction now requiring 12 hours to reach completion. On the other hand, use of both 2 mol\% and $1 \mathrm{~mol} \%$ failed to generate quantitative conversion within 24 hours, with just $48 \%$ and $27 \%$ conversion observed respectively. Consequently, it was decided that for the substrate scope, $10 \mathrm{~mol} \%$ of pre-catalyst $\mathbf{1 0}$ would be used in

Table 4 Optimisation for catalytic reactions using 10 as the precatalyst

\begin{tabular}{llllll}
\hline \multirow{2}{*}{ Entry } & $\begin{array}{l}\text { Loading } \\
\text { (mol\%) }\end{array}$ & $\begin{array}{l}\text { HBpin } \\
\text { (equiv.) }\end{array}$ & Solvent & $\begin{array}{l}\text { Time } \\
(\mathrm{h})\end{array}$ & $\begin{array}{l}\text { Conversion } \\
(\%)\end{array}$ \\
\hline 1 & 10 & 1.0 & $\mathrm{CDCl}_{3}$ & 6 & $>95^{a}$ \\
2 & 10 & 1.0 & $\mathrm{CH}_{2} \mathrm{Cl}_{2}$ & 12 & $>95^{b}$ \\
3 & 10 & 1.0 & $\mathrm{THF}_{3}$ & 24 & $76^{b}$ \\
4 & 10 & 1.0 & $\mathrm{MeCN}_{3}$ & 24 & $39^{b}$ \\
5 & 10 & 2.0 & $\mathrm{CDCl}_{3}$ & 6 & $>95^{a}$ \\
6 & 5 & 1.0 & $\mathrm{CDCl}_{3}$ & 12 & $>95^{a}$ \\
7 & 2 & 1.0 & $\mathrm{CDCl}_{3}$ & 24 & $48^{a}$ \\
8 & 1 & 1.0 & $\mathrm{CDCl}_{3}$ & 24 & $27^{a}$
\end{tabular}

${ }^{a}$ Conversion measured by in situ ${ }^{1} \mathrm{H}$ NMR spectroscopy. ${ }^{b}$ Conversion measured by in situ ${ }^{19} \mathrm{~F}$ NMR spectroscopy.

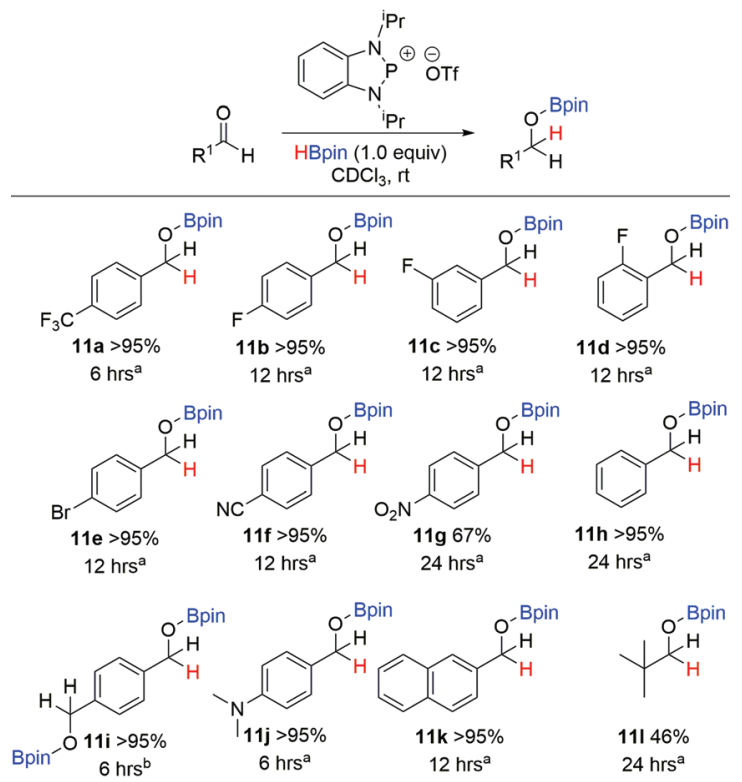

Scheme 6 Substrate scope for the hydroboration of aldehydes using a phosphenium triflate $10.0 .6 \mathrm{ml}$ of $\mathrm{CDCl}_{3}$ solvent, NMR yield calculated from in situ ${ }^{1} \mathrm{H}$ NMR spectroscopy. ${ }^{\mathrm{a}} 10 \mathrm{~mol} \%$ 10, ${ }^{\mathrm{b}} 20 \mathrm{~mol} \%$ 10, 2.0 equiv. HBpin.

$\mathrm{CDCl}_{3}$ with one equivalent of HBpin. Using these optimised conditions, a substrate scope was performed with a variety of aldehydes in order to evaluate the effectiveness of $\mathbf{1 0}$ as a precatalyst for hydroboration reduction (Scheme 6). As already discussed, 4-(trifluoromethyl)benzaldehyde was hydroborated within 6 hours using $10 \mathrm{~mol} \%$ of $\mathbf{1 0}$ to give quantitative conversion to the product 11a.

On a similar theme, use of the electron deficient fluorinated aldehydes, 4-, 3- and 2-fluorobenzaldehyde were converted to $\mathbf{1 1 b}, \mathbf{1 1}$ and $11 d$ respectively within 12 hours. In addition to fluorinated aldehydes, other electron-withdrawing aldehydes were probed. Use of both 4-bromobenzaldehyde and 4-formylbenzonitrile gave $>95 \%$ conversion to $\mathbf{1 1 e}$ and $\mathbf{1 1 f}$ respectively within 12 hours. On the other hand, when using 4-nitrobenzaldehyde, only $67 \%$ conversion to $11 \mathrm{~g}$ was detected by ${ }^{1} \mathrm{H}$ NMR spectroscopy. Benzaldehyde was slow to hydroborate, but nevertheless full conversion was observed by 24 hours, while terephthalaldehyde gave full conversion to $\mathbf{1 1 i}$ after 6 hours, albeit $20 \mathrm{~mol} \%$ of 10 was used given the presence of two aldehyde groups. The electron donating dimethylamino functional group was also tolerated, with $\mathbf{1 1} \mathbf{j}$ found in quantitative yield after 6 hours. 2-Naphthaldehyde was readily reduced to $11 \mathrm{k}$ in 12 hours. Lastly, we also tried the aliphatic pivalaldehyde, where $46 \%$ conversion to 111 was achieved after 24 hours, the approximate half product conversion we attribute partially to its high steric demand. During the course of performing the substrate scope, 4-methoxybenzaldehyde, 4-methylbenzaldehyde and 2,4,6-trimethylbenzaldehyde substrates were also examined. In these cases ${ }^{1} \mathrm{H}$ NMR spectra gave additional unidentified signals that did not correspond to 
product formation and consequently although consumption of the starting aldehyde was observed, their results are not included in Scheme 6. The ketone 4'-fluoroacetophenone was also trialled in the substrate scope, giving $57 \%$ consumption as detected by ${ }^{19} \mathrm{~F}$ NMR spectroscopy. However, additional signals to the reactant/product were identified.

Mechanistic studies on phosphenium based catalysis have been explored by Kinjo and colleagues on related hydroboration of pyridines with HBpin. ${ }^{19}$ Upon stoichiometric addition of the pre-catalyst $\mathbf{1 0}$ to 4-(trifluoromethyl)benzaldehyde, no significant change in the ${ }^{31} \mathrm{P}$ NMR spectrum was observed, indicating that there is no strong interaction between pre-catalyst and aldehyde substrate and consequently $\mathbf{1 0}$.

Mechanistically we therefore postulate that this catalysis proceeds in an analogous way to that reported by Kinjo. ${ }^{19}$ When stoichiometric amounts of $\mathbf{1 0}$ were added to HBpin to observe the active catalyst, ${ }^{31} \mathrm{P}$ NMR spectroscopy instead revealed significant decomposition product in the form of $\mathrm{PH}_{3}$, as identified by a quartet signal appearing at $\delta=$ $-238.5 \mathrm{ppm}$, with a ${ }^{1} J_{\mathrm{PH}}=189 \mathrm{~Hz}$. Furthermore, the intermediate en route to $\mathrm{PH}_{3}$ was also evident as a primary phosphine in the ${ }^{31} \mathrm{P}$ NMR spectrum (low intensity triplet at $\delta=-79.5 \mathrm{ppm}$ $\left.\left({ }^{1} J_{\mathrm{PH}}=199 \mathrm{~Hz}\right)\right)$, suggesting the formation of a primary phosphine with two $\mathrm{P}-\mathrm{H}$ bonds via endocyclic cleavage. Similar results have been observed previously by Speed for the catalytic reduction of imines using a diazaphospholene catalyst. ${ }^{44}$ Lastly, we wished to address why the different phosphole derived pre-catalysts performed so differently, and specifically to address the poor activity of the dithiaphosphole and dioxaphosphole pre-catalysts $\mathbf{6 a}$ and $9 \mathrm{a}$. To do this, stoichiometric addition of the pre-catalyst to $\mathrm{HBpin}$ in $\mathrm{CDCl}_{3}$ was performed in order to monitor how quickly the respective active hydride species formed. ${ }^{22}$ In the case of $\mathbf{6 a}$, after 24 hours, both the ${ }^{31} \mathrm{P}$ NMR and ${ }^{11} \mathrm{~B}$ NMR spectra showed little appreciable change, with no indication of a hydride species in the ${ }^{31} \mathrm{P}$ NMR spectrum and only the doublet resonance of HBpin at $28.2 \mathrm{ppm}$ was observed in the ${ }^{11} \mathrm{~B}$ NMR spectrum. For 9a, again no pre-catalyst formation was observed after 24 hours, with only a small quantity of hydrolysis product detected, as identified by a doublet signal centred at $\delta=7.7 \mathrm{ppm}\left({ }^{1} J_{\mathrm{PH}}=\right.$ $706 \mathrm{~Hz})$ in the ${ }^{31} \mathrm{P}$ NMR spectrum. These studies therefore show that the slow rate of formation of the active catalyst is the cause for the poor activity of the dithiaphosphole and dioxaphosphole pre-catalysts $\mathbf{6 a}, \mathbf{6 b}, \mathbf{9 a}$ and $\mathbf{9 b}$.

\section{Experimental}

\section{General experimental}

All reactions were carried out under an atmosphere of dinitrogen using standard Schlenk and glove box techniques. With the exception of $\mathrm{THF}$ and $\mathrm{Et}_{2} \mathrm{O}$, all solvents used were dried by passing through an alumina column incorporated into an $\mathrm{MB}$ SPS-800 solvent purification system, degassed and finally stored in an ampoule fitted with a Teflon valve under a dinitrogen atmosphere. THF and $\mathrm{Et}_{2} \mathrm{O}$ were dried over molten potass- ium for three days and distilled over argon. Deuterated solvents were distilled and dried over molecular sieves and stored in a glove box before use. Starting materials were purchased from commercial suppliers and used as received. ${ }^{1} \mathrm{H},{ }^{13} \mathrm{C}\left\{{ }^{1} \mathrm{H}\right\}$, ${ }^{19} \mathrm{~F},{ }^{11} \mathrm{~B},{ }^{31} \mathrm{P}$, and ${ }^{27} \mathrm{Al}$ NMR spectra were recorded on a Bruker Avance 300,400 , or $500 \mathrm{MHz}$ spectrometer. Chemical shifts are expressed as parts per million ( $\mathrm{ppm}, \delta$ ) and are referenced to $\mathrm{CDCl}_{3}(7.26 / 77.16 \mathrm{ppm}), \mathrm{C}_{6} \mathrm{D}_{6}(7.16 / 128.06 \mathrm{ppm})$, or $\mathrm{C}_{6} \mathrm{D}_{5} \mathrm{Br}$ (7.28/122.4 ppm for the most downfield resonance) as internal standards. Multinuclear NMR spectra were referenced to $\mathrm{BF}_{3} \cdot \mathrm{Et}_{2} \mathrm{O} / \mathrm{CDCl}_{3}\left({ }^{11} \mathrm{~B}\right), \mathrm{CFCl}_{3}\left({ }^{19} \mathrm{~F}\right), \mathrm{H}_{3} \mathrm{PO}_{4}\left({ }^{31} \mathrm{P}\right)$, and $\mathrm{Al}\left(\mathrm{NO}_{2}\right)_{3}$ $\left({ }^{27} \mathrm{Al}\right)$. The description of signals includes $\mathrm{s}=$ singlet, $\mathrm{d}=$ doublet, $\mathrm{t}=$ triplet, $\mathrm{q}=$ quartet, sept $=$ septet, and $\mathrm{m}=$ multiplet. All coupling constants are absolute values and are expressed in Hertz (Hz). IR-Spectra were measured on a Shimadzu IR Affinity- 1 photospectrometer. The description of signals includes $\mathrm{s}=$ strong, $\mathrm{m}=$ medium, $\mathrm{w}=$ weak, $\mathrm{sh}=$ shoulder, and $\mathrm{br}=$ broad. Mass spectra were measured on a Waters LCT Premier/XE or a Waters GCT Premier spectrometer.

\section{Synthesis of phosphole compounds}

General procedure 1. Phosphorus(III) chloride (1.2 equiv.) or phosphorus(III) bromide (1.0 equiv.) was added dropwise to a solution of toluene-3,4-dithiol (1.0 equiv.) or benzene dithiol (1.0 equiv.) in $\mathrm{CH}_{2} \mathrm{Cl}_{2}(3 \mathrm{~mL})$, with the evolution of gas observed. The reaction was allowed to stir at ambient temperature for 24 hours, after which the solvent was removed in vacuo. To the resulting oil, pentane $(2 \mathrm{~mL})$ was added and cooled to $-40{ }^{\circ} \mathrm{C}$ for 4 hours to give the product 2-chloro-5methylbenzo-1,3,2-dithiaphosphole (1a), 2-bromo-5-methylbenzo-1,3,2-dithiaphosphole (1b), 2-chlorobenzo-1,3,2-dithiaphosphole (2a) or 2-bromobenzo-1,3,2-dithiaphosphole (2b) as a white powder.

2-Chloro-5-methylbenzo-1,3,2-dithiaphosphole

(1a). Compound 1a was synthesised according to general procedure $\mathbf{1}$ using phosphorus(III) chloride ( $880 \mathrm{mg}, 6.40 \mathrm{mmol}, 1.2$ equiv.) and toluene-3,4-dithiol ( $1.00 \mathrm{~g}, 4.74 \mathrm{mmol}, 1.0$ equiv.). Yield: $1.363 \mathrm{~g}, 6.18 \mathrm{mmol}, 96 \%$. Crystals suitable for single crystal $\mathrm{X}$-ray diffraction were grown from a saturated solution of $\mathrm{CH}_{2} \mathrm{Cl}_{2}$ with a few drops of pentane added. ${ }^{1} \mathbf{H}$ NMR $(500 \mathrm{MHz}$, $\left.295 \mathrm{~K}, \mathrm{CDCl}_{3}\right): \delta / \mathrm{ppm} 7.55\left(\mathrm{dd},{ }^{3} J_{\mathrm{HH}}=8.1 \mathrm{~Hz},{ }^{4} J_{\mathrm{PH}}=1.2 \mathrm{~Hz}\right.$, $1 \mathrm{H}, \mathrm{Ar}-\mathrm{H}), 7.50(\mathrm{~s}, 1 \mathrm{H}, \mathrm{Ar}-\mathrm{H}), 7.12\left(\mathrm{ddd},{ }^{3} J_{\mathrm{HH}}=8.1 \mathrm{~Hz},{ }^{4} J_{\mathrm{HH}}=\right.$ $\left.1.2 \mathrm{~Hz},{ }^{5} J_{\mathrm{PH}}=0.6 \mathrm{~Hz}, 1 \mathrm{H}, \mathrm{Ar}-\mathrm{H}\right), 2.39\left(\mathrm{~s}, 3 \mathrm{H}, \mathrm{CH}_{3}\right) .{ }^{13} \mathbf{C}\left\{{ }^{1} \mathbf{H}\right\}$ NMR $\left(126 \mathrm{MHz}, 295 \mathrm{~K}, \mathrm{CDCl}_{3}\right): \delta / \mathrm{ppm} 137.9\left(\mathrm{~d},{ }^{3} J_{\mathrm{PC}}=3.3 \mathrm{~Hz}\right.$, 1C, $\mathrm{Ar}), 137.3(1 \mathrm{C}, \mathrm{Ar}), 134.4\left({ }^{3} J_{\mathrm{PC}}=3.6 \mathrm{~Hz}, 1 \mathrm{C}, \mathrm{Ar}\right), 128.1(1 \mathrm{C}$, Ar), $126.6\left(\mathrm{~d},{ }^{2} J_{\mathrm{PC}}=5.5 \mathrm{~Hz}, 1 \mathrm{C}, \mathrm{Ar}\right), 125.8\left(\mathrm{~d},{ }^{2} J_{\mathrm{PC}}=5.5 \mathrm{~Hz}, 1 \mathrm{C}\right.$, Ar), 21.1 (1C, Ar-CH $).{ }^{31} \mathbf{P}\left\{{ }^{1} \mathbf{H}\right\}$ NMR $\left(202 \mathrm{MHz}, 295 \mathrm{~K}, \mathrm{CDCl}_{3}\right)$ : $\delta /$ ppm 160.4 (s, 1P). IR $\nu_{\max }\left(\mathrm{cm}^{-1}\right): 1458(\mathrm{~m}), 1375$ (sh), 1258 $(\mathrm{w}), 1146(\mathrm{w}), 1036(\mathrm{w}), 874(\mathrm{w}), 804(\mathrm{~s}), 685(\mathrm{w})$ and $635(\mathrm{w})$. HRMS $\left(\mathrm{EI}^{+}\right) \mathrm{m} / \mathrm{z}$ calculated for $[\mathrm{M}]^{+}\left[\mathrm{C}_{7} \mathrm{H}_{6} \mathrm{ClPS}_{2}\right]^{+}:$219.9337, found: 219.9341. Melting point $38-41^{\circ} \mathrm{C}$.

2-Bromo-5-methylbenzo-1,3,2-dithiaphosphole (1b). Compound 1b was synthesised according to general procedure $\mathbf{1}$ using phosphorus(III) bromide (346 mg, $1.28 \mathrm{mmol}, 1.0$ equiv.) and toluene dithiol ( $200 \mathrm{mg}, 1.28 \mathrm{mmol}, 1.0$ equiv.). Yield: $288 \mathrm{mg}$, $1.09 \mathrm{mmol}, 85 \% .{ }^{1} \mathbf{H}$ NMR (400 MHz, $\left.295 \mathrm{~K}, \mathrm{CDCl}_{3}\right): \delta / \mathrm{ppm}$ 
$7.57\left(\mathrm{dd},{ }^{3} J_{\mathrm{HH}}=8.1 \mathrm{~Hz},{ }^{4} J_{\mathrm{PH}}=1.1 \mathrm{~Hz}, 1 \mathrm{H}, \mathrm{Ar}-\mathrm{H}\right), 7.51(\mathrm{~s}, 1 \mathrm{H}$, $\mathrm{Ar}-\mathrm{H}), 7.14\left(\mathrm{dd},{ }^{3} J_{\mathrm{HH}}=8.1 \mathrm{~Hz},{ }^{4} J_{\mathrm{HH}}=1.1 \mathrm{~Hz}, 1 \mathrm{H}, \mathrm{Ar}-\mathrm{H}\right), 2.40$ $\left(\mathrm{s}, 3 \mathrm{H}, \mathrm{CH}_{3}\right) \cdot{ }^{13} \mathbf{C}\left\{{ }^{1} \mathbf{H}\right\}$ NMR $\left(101 \mathrm{MHz}, 295 \mathrm{~K}, \mathrm{CDCl}_{3}\right): \delta / \mathrm{ppm}$ $138.8\left(\mathrm{~d},{ }^{3} J_{\mathrm{PC}}=3.2 \mathrm{~Hz}, 1 \mathrm{C}, \mathrm{Ar}\right), 137.4(1 \mathrm{C}, \mathrm{Ar}), 135.3\left(\mathrm{~d},{ }^{3} J_{\mathrm{PC}}=\right.$ $3.4 \mathrm{~Hz}, 1 \mathrm{C}, \mathrm{Ar}), 128.2$ (1C, Ar), 126.7 (d, $\left.{ }^{2} J_{\mathrm{PC}}=5.6 \mathrm{~Hz}, 1 \mathrm{C}, \mathrm{Ar}\right)$, $125.9\left(\mathrm{~d},{ }^{2} J_{\mathrm{PC}}=5.5 \mathrm{~Hz}, 1 \mathrm{C}, \mathrm{Ar}\right), 21.1\left(1 \mathrm{C}, \mathrm{Ar}-\mathrm{CH}_{3}\right) .{ }^{31} \mathbf{P}\left\{{ }^{1} \mathbf{H}\right\} \mathbf{N M R}$ (162 MHz, $\left.295 \mathrm{~K}, \mathrm{CDCl}_{3}\right): \delta / \mathrm{ppm} 163.3$ (s, 1P). IR $\nu_{\max }\left(\mathrm{cm}^{-1}\right)$ : 1456 (m), 1440 (sh), 1375 (w), 1258 (w), $1142(\mathrm{w}), 1115(\mathrm{w})$, $1036(\mathrm{w}), 999(\mathrm{w}), 947(\mathrm{w}), 876(\mathrm{w}), 817(\mathrm{~s}), 687(\mathrm{w}), 635(\mathrm{w})$ and 541 (w). HRMS $\left(\mathrm{EI}^{+}\right) \mathrm{m} / \mathrm{z}$ calculated for $[\mathrm{M}]^{+}\left[\mathrm{C}_{7} \mathrm{H}_{6} \mathrm{BrPS}_{2}\right]^{+}$: 263.8832, found: 263.8838 . Melting point $60-64{ }^{\circ} \mathrm{C}$.

2-Iodo-5-methylbenzo-1,3,2-dithiaphosphole (1c). Phosphorus(III) iodide (334 mg, $0.08 \mathrm{mmol}, 1.0$ equiv.) in $\mathrm{CH}_{2} \mathrm{Cl}_{2}$ $(2 \mathrm{~mL})$ was added dropwise to a solution of toluene-3,4-dithiol (127 mg, $0.08 \mathrm{mmol}, 1.0$ equiv.) in $\mathrm{CH}_{2} \mathrm{Cl}_{2}(3 \mathrm{~mL})$. The reaction was allowed to stir at ambient temperature for 24 hours, after which time the solvent was removed in vacuo. The resulting orange solid was washed with pentane $(3 \times 2 \mathrm{~mL})$ and again dried in vacuo, to give the product 2-iodo-5-methylbenzo-1,3,2dithiaphosphole as an orange solid. Yield: $185 \mathrm{mg}, 0.59 \mathrm{mmol}$, $73 \%$. Crystals suitable for single crystal X-ray diffraction were grown from a saturated solution of $\mathrm{CH}_{2} \mathrm{Cl}_{2}$ with a few drops of pentane added. ${ }^{1} \mathbf{H}$ NMR $\left(500 \mathrm{MHz}, 295 \mathrm{~K}, \mathrm{CDCl}_{3}\right.$ ): $\delta / \mathrm{ppm} 7.55$ $\left(\mathrm{dd},{ }^{3} J_{\mathrm{HH}}=8.1 \mathrm{~Hz},{ }^{4} J_{\mathrm{PH}}=1.3 \mathrm{~Hz}, 1 \mathrm{H}, \mathrm{Ar}-\mathrm{H}\right), 7.50(\mathrm{~s}, 1 \mathrm{H}, \mathrm{Ar}-\mathrm{H})$, $7.15\left(\mathrm{ddd},{ }^{3} \mathrm{~J}_{\mathrm{HH}}=8.1 \mathrm{~Hz},{ }^{4} J_{\mathrm{HH}}=1.6 \mathrm{~Hz},{ }^{5} J_{\mathrm{PH}}=0.7 \mathrm{~Hz} 1 \mathrm{H}\right.$, $\mathrm{Ar}-\mathrm{H}), 2.41$ (s, 3H, CH$\left.{ }_{3}\right) .{ }^{13} \mathbf{C}\left\{{ }^{1} \mathbf{H}\right\}$ NMR (126 MHz, $295 \mathrm{~K}$, $\mathrm{CDCl}_{3}$ ): $\delta / \mathrm{ppm} 140.2$ (d, $\left.{ }^{3} J_{\mathrm{PC}}=3.1 \mathrm{~Hz}, 1 \mathrm{C}, \mathrm{Ar}\right), 137.5(1 \mathrm{C}, \mathrm{Ar}$ ), $136.7\left({ }^{3} J_{\mathrm{PC}}=3.1 \mathrm{~Hz}, 1 \mathrm{C}, \mathrm{Ar}\right), 128.2(1 \mathrm{C}, \mathrm{Ar}), 127.0\left(\mathrm{~d},{ }^{2} J_{\mathrm{PC}}=\right.$ $5.6 \mathrm{~Hz}, 1 \mathrm{C}, \mathrm{Ar}), 126.2\left(\mathrm{~d},{ }^{2} J_{\mathrm{PC}}=5.6 \mathrm{~Hz}, 1 \mathrm{C}, \mathrm{Ar}\right), 21.1(1 \mathrm{C}$, $\left.\mathrm{Ar}-\mathrm{CH}_{3}\right) .{ }^{31} \mathbf{P}\left\{{ }^{1} \mathbf{H}\right\}$ NMR $\left(202 \mathrm{MHz}, 295 \mathrm{~K}, \mathrm{CDCl}_{3}\right): \delta / \mathrm{ppm} 155.0$ (s, 1P). IR $\nu_{\max }\left(\mathrm{cm}^{-1}\right): 1458(\mathrm{w}), 1379(\mathrm{w}), 1254(\mathrm{w}), 854(\mathrm{w})$, $804(\mathrm{~s}), 692(\mathrm{w}), 637(\mathrm{w})$ and $538(\mathrm{w})$. HRMS $\left(\mathrm{EI}^{+}\right) \mathrm{m} / \mathrm{z}$ calculated for $[\mathrm{M}]^{+}\left[\mathrm{C}_{7} \mathrm{H}_{6} \mathrm{IPS}_{2}\right]^{+}: 311.8693$, found: 311.8687 . Melting point $86-90{ }^{\circ} \mathrm{C}$.

5-Methyl- $N, N$-bis(trimethylsilyl)benzo-1,3,2-dithiaphosphol2-amine (1d). 2-Chloro-5-methylbenzo-1,3,2-dithiaphosphole (1a) (241 mg, $1.09 \mathrm{mmol}, 1.0$ equiv.) dissolved in toluene ( $5 \mathrm{~mL}$ ) was added dropwise to lithium bis(trimethylsilyl)amide (183 mg, $1.09 \mathrm{mmol}, 1.0$ equiv.) dissolved in toluene (5 mL) at $0{ }^{\circ} \mathrm{C}$, using an ice bath. The reaction was allowed to slowly warm to ambient temperature and left to stir for 18 hours. LiCl salt was removed via filtering the yellow solution, which the solvent was removed in vacuo to give the product as a yellow oil. Yield: $354 \mathrm{mg}, 1.02 \mathrm{mmol}, 94 \% .{ }^{1} \mathbf{H}$ NMR (500 MHz, $295 \mathrm{~K}$, $\mathrm{CDCl}_{3}$ ): $\delta / \mathrm{ppm} 7.38\left(\mathrm{~d},{ }^{3} J_{\mathrm{HH}}=8.0 \mathrm{~Hz}, 1 \mathrm{H}, \operatorname{Ar}-\mathrm{H}\right), 7.33(\mathrm{~s}, 1 \mathrm{H}$, $\mathrm{Ar}-\mathrm{H}), 6.96\left(\mathrm{~d},{ }^{3} J_{\mathrm{HH}}=8.0 \mathrm{~Hz}, 1 \mathrm{H}, \mathrm{Ar}-\mathrm{H}\right), 2.36\left(\mathrm{~s}, 3 \mathrm{H}, \mathrm{CH}_{3}\right), 0.27$ $\left(\mathrm{s},{ }^{2} J_{\mathrm{SiH}}=1.9 \mathrm{~Hz}, 18 \mathrm{H}, \mathrm{SiMe}_{3}\right) \cdot{ }^{13} \mathbf{C}\left\{{ }^{1} \mathbf{H}\right\} \mathbf{N M R}(126 \mathrm{MHz}, 295 \mathrm{~K}$, $\mathrm{CDCl}_{3}$ ): $\delta / \mathrm{ppm} 141.1$ (1C, Ar), 137.7 (1C, Ar), 134.9 (1C, Ar), $126.2(1 \mathrm{C}, \mathrm{Ar}), 124.7\left(\mathrm{~d},{ }^{2} J_{\mathrm{PC}}=8.3 \mathrm{~Hz}, 1 \mathrm{C}, \mathrm{Ar}\right), 123.9\left(\mathrm{~d},{ }^{2} J_{\mathrm{PC}}=\right.$ $8.3 \mathrm{~Hz}, 1 \mathrm{C}, \mathrm{Ar}), 20.9\left(1 \mathrm{C}, \mathrm{Ar}-\mathrm{CH}_{3}\right), 4.26\left(\mathrm{~d},{ }^{1} J_{\mathrm{SiC}}=9.7 \mathrm{~Hz}, 6 \mathrm{C}\right.$, $\mathrm{SiMe}_{3}$ ). ${ }^{31} \mathbf{P}\left\{{ }^{\mathbf{1}} \mathbf{H}\right\}$ NMR $\left(202 \mathrm{MHz}, 295 \mathrm{~K}, \mathrm{CDCl}_{3}\right.$ ): $\delta /$ ppm 93.9 (s, 1P). HRMS $\left(\mathrm{ES}^{+}\right) \mathrm{m} / \mathrm{z}$ calculated for $[\mathrm{M}+\mathrm{H}]^{+}\left[\mathrm{C}_{13} \mathrm{H}_{25} \mathrm{NSi}_{2} \mathrm{PS}_{2}\right]^{+}$: 346.0705, found: 346.0714 .

tris(5-Methylbenzo-1,3,2-dithiaphosphol-2-yl)amine

(1e). 5-Methyl- $N, N$-bis(trimethylsilyl)benzo-1,3,2-dithiaphosphol-2amine (1d) (300 mg, $0.91 \mathrm{mmol}, 1.0$ equiv.) in $\mathrm{MeCN}(10 \mathrm{~mL})$ was added dropwise to a solution of 2-chloro-5-methylbenzo1,3,2-dithiaphosphole (1a) (401 mg, $1.82 \mathrm{mmol}, 2.0$ equiv.) in MeCN $(10 \mathrm{~mL})$ at $0{ }^{\circ} \mathrm{C}$. The mixture was allowed to slowly warm to ambient temperature before being heated to reflux for 16 hours. The resulting solution was cooled in an ice bath at $0{ }^{\circ} \mathrm{C}$ for three hours to give a white precipitate. The MeCN was removed via filter cannula and the white solid was washed with pentane $(3 \times 10 \mathrm{~mL})$. After which the solid was dried in vacuo to give the product tris (5-methylbenzo-1,3,2-dithiaphosphol-2-yl)amine (1e) as a white solid. Yield: $451 \mathrm{mg}$, $0.79 \mathrm{mmol}, 87 \% .{ }^{1} \mathbf{H}$ NMR $\left(500 \mathrm{MHz}, 295 \mathrm{~K}, \mathrm{CDCl}_{3}\right): \delta / \mathrm{ppm}$ $7.42\left(\mathrm{~d},{ }^{3} J_{\mathrm{HH}}=8.1 \mathrm{~Hz}, 1 \mathrm{H}, \operatorname{Ar}-\mathrm{H}\right), 7.36(\mathrm{~s}, 1 \mathrm{H}, \mathrm{Ar}-\mathrm{H}), 6.99(\mathrm{~d}$, $\left.{ }^{3} J_{\mathrm{HH}}=8.1 \mathrm{~Hz}, 1 \mathrm{H}, \mathrm{Ar}-\mathrm{H}\right), 2.34\left(\mathrm{~s}, 3 \mathrm{H}, \mathrm{CH}_{3}\right) .{ }^{13} \mathbf{C}\left\{{ }^{1} \mathbf{H}\right\} \mathbf{N M R}$ (126 MHz, $295 \mathrm{~K}, \mathrm{CDCl}_{3}$ ): $\delta /$ ppm 139.7 (1C, Ar), 136.3 (1C, Ar), 136.1 (1C, Ar), 127.3 (1C, Ar), 125.1 (1C, Ar), 124.3 (1C, Ar), 21.1 (1C, Ar- $\left.\mathrm{CH}_{3}\right) .{ }^{31} \mathbf{P}\left\{{ }^{1} \mathbf{H}\right\}$ NMR (202 MHz, $\left.295 \mathrm{~K}, \mathrm{CDCl}_{3}\right)$ : $\delta /$ ppm $86.6(\mathrm{~s}, 1 \mathrm{P})$. Elemental analysis Found (Calc. for $\mathrm{C}_{21} \mathrm{H}_{18} \mathrm{NP}_{3} \mathrm{~S}_{6}$ ): $\mathrm{C}=43.94 \%$ (44.27); $\mathrm{H}=3.00 \%(3.18) \mathrm{N}=2.73 \%$ (2.46). IR $\nu_{\max }\left(\mathrm{cm}^{-1}\right): 1456(\mathrm{~m}), 1375(\mathrm{w}), 1258(\mathrm{w}), 1115(\mathrm{w})$, $775(\mathrm{br}, \mathrm{s})$ and $685(\mathrm{w})$. HRMS $\left(\mathrm{AP}^{+}\right) \mathrm{m} / z$ calculated for $[\mathrm{M}+\mathrm{H}]^{+}$ $\left[\mathrm{C}_{21} \mathrm{H}_{19} \mathrm{NP}_{3} \mathrm{~S}_{6}\right]^{+}$: 569.9055, found: 569.9059. Melting point 150-152 ${ }^{\circ} \mathrm{C}$.

2-Chlorobenzo-1,3,2-dithiaphosphole (2a). Compound 2a was synthesised according to general procedure 1 using phosphorus(III) chloride (89 mg, $0.65 \mathrm{mmol}, 1.2$ equiv.) and benzene dithiol (77 mg, $0.54 \mathrm{mmol}, 1.0$ equiv.). Yield: $104 \mathrm{mg}$, $0.50 \mathrm{mmol}, 93 \%$. Crystals suitable for single crystal X-ray diffraction were grown from a saturated solution of $\mathrm{CH}_{2} \mathrm{Cl}_{2}$ with a few drops of pentane added. ${ }^{1} \mathbf{H}$ NMR $(400 \mathrm{MHz}, 295 \mathrm{~K}$, $\left.\mathrm{CDCl}_{3}\right): \delta / \mathrm{ppm} 7.69\left(\mathrm{ddd},{ }^{3} J_{\mathrm{HH}}=5.9 \mathrm{~Hz},{ }^{4} J_{\mathrm{HH}}=3.3 \mathrm{~Hz},{ }^{4} J_{\mathrm{PH}}=\right.$ $1.3 \mathrm{~Hz}, 2 \mathrm{H}, \mathrm{Ar}-\mathrm{H}), 7.32\left(\mathrm{dd},{ }^{3} J_{\mathrm{HH}}=5.9 \mathrm{~Hz},{ }^{4} J_{\mathrm{HH}}=3.3 \mathrm{~Hz}, 2 \mathrm{H}\right.$, $\mathrm{Ar}-\mathrm{H}) .{ }^{13} \mathbf{C}\left\{{ }^{1} \mathbf{H}\right\}$ NMR $\left(101 \mathrm{MHz}, 295 \mathrm{~K}, \mathrm{CDCl}_{3}\right): \delta / \mathrm{ppm} 137.8$ (d, $\left.{ }^{3} J_{\mathrm{PC}}=3.3 \mathrm{~Hz}, 2 \mathrm{C}, \mathrm{Ar}\right), 126.9(2 \mathrm{C}, \mathrm{Ar}), 126.1$ (d, ${ }^{2} J_{\mathrm{PC}}=5.6 \mathrm{~Hz}, 2 \mathrm{C}$, Ar). ${ }^{31} \mathbf{P}\left\{{ }^{1} \mathbf{H}\right\}$ NMR (162 MHz, $\left.295 \mathrm{~K}, \mathrm{CDCl}_{3}\right): \delta / \mathrm{ppm} 158.3(\mathrm{~s}$, 1P). IR $\nu_{\max }\left(\mathrm{cm}^{-1}\right): 1441(\mathrm{~m}), 1429(\mathrm{sh}), 1252(\mathrm{w}), 1103(\mathrm{w})$, 937 (w), 743 (s) and $662(\mathrm{w})$. HRMS $\left(\mathrm{EI}^{+}\right) \mathrm{m} / \mathrm{z}$ calculated for $[\mathrm{M}]^{+}\left[\mathrm{C}_{6} \mathrm{H}_{4} \mathrm{ClPS}_{2}\right]^{+}:$205.9181, found: 205.9176. Melting point $40-42{ }^{\circ} \mathrm{C}$.

2-Bromobenzo-1,3,2-dithiaphosphole (2b). Compound $2 \mathrm{~b}$ was synthesised according to general procedure 1 using phosphorus(III) bromide (186 mg, $0.69 \mathrm{mmol}, 1.0$ equiv.) and benzene dithiol (98 mg, $0.69 \mathrm{mmol}, 1.0$ equiv.). Yield: $157 \mathrm{mg}$ g, $0.62 \mathrm{mmol}, 91 \%$. Crystals suitable for single crystal X-ray diffraction were grown from a saturated solution of $\mathrm{CH}_{2} \mathrm{Cl}_{2}$ with a few drops of pentane added. ${ }^{1} \mathbf{H}$ NMR $(400 \mathrm{MHz}, 295 \mathrm{~K}$, $\left.\mathrm{CDCl}_{3}\right): \delta / \mathrm{ppm} 7.70\left(\mathrm{ddd},{ }^{3} J_{\mathrm{HH}}=5.9 \mathrm{~Hz},{ }^{4} J_{\mathrm{HH}}=3.3 \mathrm{~Hz},{ }^{4} J_{\mathrm{PH}}=\right.$ $1.3 \mathrm{~Hz}, 2 \mathrm{H}, \mathrm{Ar}-\mathrm{H}), 7.33\left(\mathrm{dd},{ }^{3} J_{\mathrm{HH}}=5.9 \mathrm{~Hz},{ }^{4} J_{\mathrm{HH}}=3.3 \mathrm{~Hz}, 2 \mathrm{H}\right.$, $\mathrm{Ar}-\mathrm{H}) .{ }^{13} \mathbf{C}\left\{{ }^{1} \mathbf{H}\right\}$ NMR (101 MHz, $295 \mathrm{~K}, \mathrm{CDCl}_{3}$ ): $\delta / \mathrm{ppm} 138.6$ (d, $\left.{ }^{3} J_{\mathrm{PC}}=3.3 \mathrm{~Hz}, 2 \mathrm{C}, \mathrm{Ar}\right), 127.0$ (2C, Ar), 126.3 (d, ${ }^{2} J_{\mathrm{PC}}=5.7 \mathrm{~Hz}, 2 \mathrm{C}$, Ar). ${ }^{31} \mathbf{P}\left\{{ }^{1} \mathbf{H}\right\}$ NMR $\left(162 \mathrm{MHz}, 295 \mathrm{~K}, \mathrm{CDCl}_{3}\right): \delta / \mathrm{ppm} 160.9$ (s, 1P). IR $\nu_{\max }\left(\mathrm{cm}^{-1}\right): 1441(\mathrm{~m}), 1425(\mathrm{sh}), 1252(\mathrm{w}), 936(\mathrm{w})$, 741 (s) and $662(\mathrm{w})$. HRMS $\left(\mathrm{EI}^{+}\right) \mathrm{m} / \mathrm{z}$ calculated for $[\mathrm{M}]^{+}$ $\left[\mathrm{C}_{6} \mathrm{H}_{4} \mathrm{BrPS}_{2}\right]^{+}:$249.8675, found: 249.8682. Melting point 62-64 ${ }^{\circ} \mathrm{C}$.

2-Iodobenzo-1,3,2-dithiaphosphole (2c). Phosphorus(III) iodide (517 mg, $1.26 \mathrm{mmol}, 1.0$ equiv.) in $\mathrm{CH}_{2} \mathrm{Cl}_{2}$ (2 mL) was 
added dropwise to a solution of benzene dithiol (179 mg, 1.26 mmol, 1.0 equiv.) in $\mathrm{CH}_{2} \mathrm{Cl}_{2}(3 \mathrm{~mL})$. The reaction was allowed to stir at ambient temperature for 24 hours, after which time the solvent was removed in vacuo. The resulting red solid was washed with pentane $(3 \times 2 \mathrm{~mL})$ and again dried in vacuo, to give the product 2-iodobenzo-1,3,2-dithiaphosphole as a red solid. Yield: $312 \mathrm{mg}, 1.0 \mathrm{mmol}, 83 \%$. Crystals suitable for single crystal X-ray diffraction were grown from a saturated solution of $\mathrm{CH}_{2} \mathrm{Cl}_{2}$ with a few drops of pentane added. ${ }^{1} \mathbf{H}$ NMR $\left(500 \mathrm{MHz}, 295 \mathrm{~K}, \mathrm{CDCl}_{3}\right.$ ): $\delta / \mathrm{ppm} 7.68$ (ddd, $\left.{ }^{3} J_{\mathrm{HH}}=5.9 \mathrm{~Hz},{ }^{4} J_{\mathrm{HH}}=3.3 \mathrm{~Hz},{ }^{4} J_{\mathrm{PH}}=1.3 \mathrm{~Hz}, 2 \mathrm{H}, \mathrm{Ar}-\mathrm{H}\right), 7.34(\mathrm{dd}$, $\left.{ }^{3} J_{\mathrm{HH}}=5.9 \mathrm{~Hz},{ }^{4} J_{\mathrm{HH}}=3.3 \mathrm{~Hz}, 2 \mathrm{H}, \mathrm{Ar}-\mathrm{H}\right) .{ }^{13} \mathbf{C}\left\{{ }^{1} \mathbf{H}\right\} \mathbf{N M R}$ (126 MHz, $295 \mathrm{~K}, \mathrm{CDCl}_{3}$ ): $\delta / \mathrm{ppm}: 140.0\left(\mathrm{~d},{ }^{3} J_{\mathrm{PC}}=3.3 \mathrm{~Hz}, 2 \mathrm{C}\right.$, Ar), 127.0 (2C, Ar), 126.5 (d, $\left.{ }^{2} J_{\mathrm{PC}}=5.7 \mathrm{~Hz}, 2 \mathrm{C}, \mathrm{Ar}\right) .{ }^{31} \mathbf{P}\left\{{ }^{1} \mathbf{H}\right\}$ NMR (202 MHz, $295 \mathrm{~K}, \mathrm{CDCl}_{3}$ ): $\delta / \mathrm{ppm} 152.4$ (s, 1P). IR $\nu_{\max }$ $\left(\mathrm{cm}^{-1}\right): 1439(\mathrm{~m}), 1420(\mathrm{sh}), 784(\mathrm{~s})$ and $662(\mathrm{w})$. HRMS $\left(\mathrm{EI}^{+}\right)$ $m / z$ calculated for $[\mathrm{M}]^{+}\left[\mathrm{C}_{6} \mathrm{H}_{4} \mathrm{IPS}_{2}\right]^{+}: 297.8537$, found: 297.8537 . Melting point $76-78^{\circ} \mathrm{C}$.

5-Methylbenzo-1,3,2-dithiaphosphenium tetrachloroaluminate (3a). 2-Chloro-5-methylbenzo-1,3,2-dithiaphosphole (103 mg, $0.47 \mathrm{mmol}, 1.0$ equiv.) in $\mathrm{CH}_{2} \mathrm{Cl}_{2}(3 \mathrm{~mL}$ ) was added to aluminium(III) chloride (62 $\mathrm{mg}, 0.47 \mathrm{mmol}, 1.0$ equiv.) in $\mathrm{CH}_{2} \mathrm{Cl}_{2}(2 \mathrm{~mL})$ and left to stir at ambient temperature for 6 hours. After this the solvent was removed in vacuo and washed with pentane $(3 \times 2 \mathrm{~mL})$ and dried again in vacuo, giving the product 5-methylbenzo-1,3,2-dithiaphosphenium tetrachloroaluminate as a highly air-sensitive orange powder. Yield: $139 \mathrm{mg}, 0.39 \mathrm{mmol}, 83 \% .{ }^{27} \mathrm{Al}$ NMR (130 MHz, $295 \mathrm{~K}$, $\mathrm{C}_{6} \mathrm{D}_{5} \mathrm{Br}$ ): $\delta / \mathrm{ppm} 103.9$ (s, $1 \mathrm{Al}, \mathrm{AlCl}_{4}{ }^{-}$). HRMS $\left(\mathrm{EI}^{+}\right) \mathrm{m} / z$ calculated for $[\mathrm{M}]^{+}\left[\mathrm{C}_{7} \mathrm{H}_{6} \mathrm{PS}_{2}\right]^{+}:$184.9649, found: 184.9649. IR $\nu_{\max }$ $\left(\mathrm{cm}^{-1}\right)$ : 1582 (w), 1458 (m), 1381 (w), 1261 (w), 1168 (br, m), 964 (br, m), and 802 (w). Melting Point 126-130 ${ }^{\circ} \mathrm{C}$.

Note: Attempted recrystallisation of $\mathbf{3 a}$ from THF afforded 1a and a set of colourless crystals which were identified as $\mathrm{AlCl}_{3} \cdot 2 \mathrm{THF}$ by X-ray crystallography (identical to that reported previously). ${ }^{46}$

5-Methylbenzo-1,3,2-dithiaphosphenium tetrachloro gallate (3b). 2-Chloro-5-methylbenzo-1,3,2-dithiaphosphole (347 mg, 1.57 mmol, 1.0 equiv.) in $\mathrm{CH}_{2} \mathrm{Cl}_{2}(3 \mathrm{~mL})$ was added to gallium(III) chloride (277 mg, $1.57 \mathrm{mmol}, 1.0$ equiv.) in $\mathrm{CH}_{2} \mathrm{Cl}_{2}$ $(2 \mathrm{~mL})$ and left to stir at ambient temperature for 12 hours. After this the solvent was removed in vacuo and washed with pentane $(3 \times 2 \mathrm{~mL})$ and dried again in vacuo, giving the product 5-methylbenzo-1,3,2-dithiaphosphenium tetrachloro gallate as a highly air-sensitive orange powder. Yield: $492 \mathrm{mg}$, $1.24 \mathrm{mmol}, 79 \%$. Crystals suitable for single crystal X-ray diffraction were grown from a saturated solution of $\mathrm{CH}_{2} \mathrm{Cl}_{2}$ with a few drops of pentane added. ${ }^{1} \mathbf{H}$ NMR $(500 \mathrm{MHz}, 295 \mathrm{~K}$, $\left.\mathrm{C}_{6} \mathrm{D}_{5} \mathrm{Br}\right): \delta / \mathrm{ppm} 7.64\left(\mathrm{~d},{ }^{3} J_{\mathrm{HH}}=8.3 \mathrm{~Hz}, 1 \mathrm{H}, \mathrm{Ar}-\mathrm{H}\right), 7.43(\mathrm{~s}, 1 \mathrm{H}$, $\mathrm{Ar}-\mathrm{H}), 7.08\left(\mathrm{~d},{ }^{3} J_{\mathrm{HH}}=8.3 \mathrm{~Hz}, 1 \mathrm{H}, \mathrm{Ar}-\mathrm{H}\right), 2.16\left(\mathrm{~s}, 3 \mathrm{H}, \mathrm{CH}_{3}\right)$. HRMS $\left(\mathrm{EI}^{+}\right) \mathrm{m} / \mathrm{z}$ calculated for $[\mathrm{M}]^{+}\left[\mathrm{C}_{7} \mathrm{H}_{6} \mathrm{PS}_{2}\right]^{+}:$184.9649, found: 184.9650. IR $\nu_{\max }\left(\mathrm{cm}^{-1}\right): 1582(\mathrm{w}), 1462(\mathrm{~m}), 1383(\mathrm{w})$, 1312 (w), 1099 (br, s), 966 (br, m), 872 (w) and 810 (s). Melting Point $104-106{ }^{\circ} \mathrm{C}$.

General procedure 2. A suspension of $1 \mathbf{a}$ or $2 \mathbf{a}$ (1 equiv.) and finely chopped sodium (2.7 equiv.) in toluene $(20 \mathrm{~mL})$ was stirred at $100{ }^{\circ} \mathrm{C}$ for 4 days and monitored by ${ }^{31} \mathrm{P}$ NMR spectroscopy. After completion, the reaction mixture was filtered and the filtrate evaporated in vacuo to afford a yellow solid. Recrystallisation by slow evaporation of a toluene solution afforded very pale-yellow crystals of the dimer product 4 or 5 .

1,3,2-Benzodithiaphosphoryl dimer (4). Compound 4 was synthesised according to general procedure 2 using 2 a (1.00 g, $4.84 \mathrm{mmol}, 1$ equiv.) and sodium (300 mg, $13.0 \mathrm{mmol}, 2.7$ equiv.). Yield: $413 \mathrm{mg}, 1.21 \mathrm{mmol}, 50 \% .{ }^{1} \mathbf{H}$ NMR $(500 \mathrm{MHz}$, $295 \mathrm{~K}, \mathrm{CDCl}_{3}$ ): $\delta / \mathrm{ppm} 7.03-7.01(\mathrm{~m}, 4 \mathrm{H}, \mathrm{Ar}-\mathrm{H}), 6.63-6.61$ (m, $4 \mathrm{H}, \mathrm{Ar}-\mathrm{H}) .{ }^{31} \mathbf{P}\left\{{ }^{1} \mathbf{H}\right\}$ NMR $\left(202 \mathrm{MHz}, 295 \mathrm{~K}, \mathrm{CDCl}_{3}\right): \delta / \mathrm{ppm}$ $38.3(\mathrm{~s}, 2 \mathrm{P})$. Elemental analysis Found (Calc. for $\mathrm{C}_{14} \mathrm{H}_{12} \mathrm{P}_{2} \mathrm{~S}_{4}$ ): $\mathrm{C}=43.2 \%$ (42.1); $\mathrm{H}=2.9 \%$ (2.4). Melting point $224-225{ }^{\circ} \mathrm{C}$.

5-Methyl-1,3,2-benzodithiaphosphoryl dimer (5). Compound 5 was synthesised according to general procedure 2 using $\mathbf{1 a}$ (1.07 g, 4.85 mmol, 1 equiv.) and sodium (300 mg, $13.0 \mathrm{mmol}$, 2.7 equiv.). Yield: $630 \mathrm{mg}, 1.70 \mathrm{mmol}, 70 \%$. ${ }^{\mathbf{1}} \mathbf{H}$ NMR (300 MHz, $295 \mathrm{~K}, \mathrm{CD}_{2} \mathrm{Cl}_{2}$ ): $\delta / \mathrm{ppm} 7.35\left(\mathrm{~d},{ }^{3} J_{\mathrm{HH}}=8.1 \mathrm{~Hz}, 2 \mathrm{H}\right.$, $\mathrm{Ar}-\mathrm{H}), 7.31$ (s, 2H, Ar-H), $6.98\left(\mathrm{~d},{ }^{3} J_{\mathrm{HH}}=8.1 \mathrm{~Hz}, 2 \mathrm{H}, \mathrm{Ar}-\mathrm{H}\right)$, 2.31 (s, 6H, $\left.\mathrm{CH}_{3}\right) .{ }^{31} \mathbf{P}\left\{{ }^{1} \mathbf{H}\right\}$ NMR (121 MHz, $\left.295 \mathrm{~K}, \mathrm{CDCl}_{3}\right)$ : $\delta / \mathrm{ppm} 40.6(\mathrm{~s}, 2 \mathrm{P})$. Elemental analysis Found (Calc. for $\mathrm{C}_{14} \mathrm{H}_{12} \mathrm{P}_{2} \mathrm{~S}_{4}$ ): $\mathrm{C}=45.5 \%$ (45.4); $\mathrm{H}=3.3 \%$ (3.3). Melting point 221-222 ${ }^{\circ} \mathrm{C}$.

General procedure 3. To a solution of 2-chloro-5-methylbenzo-1,3,2-dithiaphosphole (1.0 equiv.) in $\mathrm{CH}_{2} \mathrm{Cl}_{2}(5 \mathrm{~mL})$, benzyl alcohol (1.0 equiv.) or neopentyl alcohol (1.0 equiv.) and triethyl amine (1.0 equiv.) were added dropwise. The reaction was allowed to stir at ambient temperature for 24 hours, after which the solvent was removed in vacuo. Toluene $(2 \mathrm{~mL})$ was subsequently added and the resulting solution was filtered through a plug of Celite to remove traces of ammonium salt, after which the solvent was again removed in vacuo to give the product.

2-(Benzyloxy)-5-methylbenzo-1,3,2-dithiaphosphole (6a). Compound $\mathbf{6}$ a was synthesised according to general procedure 3 using 1a (199 mg, $0.91 \mathrm{mmol}, 1.0$ equiv.) and benzyl alcohol (97 mg, $0.91 \mathrm{mmol}, 1.0$ equiv.). Yield: $167 \mathrm{mg}, 0.57 \mathrm{mmol}$, $63 \% .{ }^{1} \mathbf{H}$ NMR $\left(400 \mathrm{MHz}, 295 \mathrm{~K}, \mathrm{CDCl}_{3}\right): \delta / \mathrm{ppm} 7.50\left(\mathrm{~d},{ }^{3} \mathrm{~J}_{\mathrm{HH}}=\right.$ $8.1 \mathrm{~Hz}, 1 \mathrm{H}, \mathrm{Ar}-\mathrm{H}), 7.44$ (s, 1H, Ar-H), 7.28-7.25 (m, 3H, Ar-H), $7.16-7.14(\mathrm{~m}, 2 \mathrm{H}, \mathrm{Ar}-\mathrm{H}), 7.02\left(\mathrm{ddd},{ }^{3} J_{\mathrm{HH}}=8.1 \mathrm{~Hz},{ }^{4} J_{\mathrm{HH}}=\right.$ $\left.1.7 \mathrm{~Hz},{ }^{5} J_{\mathrm{PH}}=0.7 \mathrm{~Hz}, 1 \mathrm{H}, \mathrm{Ar}-\mathrm{H}\right), 4.22\left(\mathrm{~d},{ }^{3} J_{\mathrm{PH}}=6.5 \mathrm{~Hz}, 2 \mathrm{H}\right.$, $\mathrm{OCH}_{2}$ ), 2.36 (s, 3H, Ar- $\left.\mathrm{CH}_{3}\right) .{ }^{13} \mathbf{C}\left\{{ }^{1} \mathbf{H}\right\}$ NMR (101 MHz, $295 \mathrm{~K}$, $\left.\mathrm{CDCl}_{3}\right): \delta / \mathrm{ppm}: 139.7\left(\mathrm{~d},{ }^{3} J_{\mathrm{PC}}=3.0 \mathrm{~Hz}, 1 \mathrm{C}, \mathrm{Ar}\right), 136.8\left({ }^{3} J_{\mathrm{PC}}=\right.$ $2.5 \mathrm{~Hz}, 1 \mathrm{C}, \mathrm{Ar}), 136.2\left({ }^{3} J_{\mathrm{PC}}=3.2 \mathrm{~Hz}, 1 \mathrm{C}, \mathrm{Ar}\right), 136.1$ (1C, Ar), 129.2 (1C, Ar), 128.5 (1C, Ar), 128.2 (1C, Ar), 128.0 (1C, Ar), 127.1 (1C, Ar), 125.4 (1C, Ar), 124.9 (d, ${ }^{2} J_{\mathrm{PC}}=6.4 \mathrm{~Hz}, 1 \mathrm{C}, \mathrm{Ar}$ ), $124.1\left(\mathrm{~d},{ }^{2} J_{\mathrm{PC}}=6.3 \mathrm{~Hz}, 1 \mathrm{C}, \mathrm{Ar}\right), 67.9\left(\mathrm{~d},{ }^{2} J_{\mathrm{PC}}=9.1 \mathrm{~Hz}, 1 \mathrm{C}\right.$, $\mathrm{Ar}-\mathrm{CH} 2) 21.0$ (1C, $\left.\mathrm{Ar}-\mathrm{CH}_{3}\right) .{ }^{31} \mathbf{P}$ NMR (162 MHz, $\left.295 \mathrm{~K}, \mathrm{CDCl}_{3}\right)$ : $\delta /$ ppm $124.5\left(\mathrm{t},{ }^{3} J_{\mathrm{PH}}=6.5 \mathrm{~Hz}, 1 \mathrm{P}\right) . \mathbf{I R} \nu_{\max }\left(\mathrm{cm}^{-1}\right): 1456(\mathrm{~m})$, 1364 (sh), 1217 (w), 1115 (w), 955 (s), 910 (sh), 725 (m), 689 (m) and $586(\mathrm{w})$. HRMS $\left(\mathrm{EI}^{+}\right) \mathrm{m} / \mathrm{z}$ calculated for $[\mathrm{M}]^{+}\left[\mathrm{C}_{15} \mathrm{H}_{13} \mathrm{OPS}_{2}\right]^{+}$: 292.0145, found: 292.0148 .

5-Methyl-2-(neopentyloxy)benzo-1,3,2-dithiaphosphole (6b). Compound $\mathbf{6 b}$ was synthesised according to general procedure 3 using 1a (223 mg, $1.01 \mathrm{mmol}, 1.0$ equiv.) and neopentyl alcohol (89 mg, $1.01 \mathrm{mmol}, 1.0$ equiv.). Yield: $179 \mathrm{mg}$, 
$0.66 \mathrm{mmol}, 65 \% .{ }^{1} \mathbf{H}$ NMR $\left(400 \mathrm{MHz}, 295 \mathrm{~K}, \mathrm{CDCl}_{3}\right): \delta / \mathrm{ppm}$ $7.46\left(\mathrm{~d},{ }^{3} \mathrm{~J}_{\mathrm{HH}}=8.1 \mathrm{~Hz}, 1 \mathrm{H}, \mathrm{Ar}-\mathrm{H}\right), 7.40$ (s, 1H, Ar-H), 6.99 (ddd, $\left.{ }^{3} J_{\mathrm{HH}}=8.1 \mathrm{~Hz},{ }^{4} J_{\mathrm{HH}}=1.2 \mathrm{~Hz},{ }^{5} J_{\mathrm{PH}}=0.5 \mathrm{~Hz}, 1 \mathrm{H}, \mathrm{Ar}-\mathrm{H}\right), 2.85(\mathrm{~d}$, $\left.{ }^{3} J_{\mathrm{PH}}=6.1 \mathrm{~Hz}, 2 \mathrm{H}, \mathrm{OCH}_{2}\right), 2.36\left(\mathrm{~s}, 3 \mathrm{H}, \mathrm{Ar}-\mathrm{CH}_{3}\right), 0.77(\mathrm{~s}, 9 \mathrm{H}$, $\left.\mathrm{CH}_{2}\left(\mathrm{CH}_{3}\right)_{3}\right) .{ }^{13} \mathrm{C}\left\{{ }^{1} \mathbf{H}\right\}$ NMR (101 MHz, $\left.295 \mathrm{~K}, \mathrm{CDCl}_{3}\right): \delta / \mathrm{ppm}:$ $139.9\left(\mathrm{~d},{ }^{3} J_{\mathrm{PC}}=2.9 \mathrm{~Hz}, 1 \mathrm{C}, \mathrm{Ar}\right), 136.4\left(\mathrm{~d},{ }^{3} J_{\mathrm{PC}}=3.2 \mathrm{~Hz}, 1 \mathrm{C}, \mathrm{Ar}\right)$, 135.8 (1C, Ar), 126.9 (1C, Ar), 124.8 (d, ${ }^{2} J_{\mathrm{PC}}=6.5 \mathrm{~Hz}, 1 \mathrm{C}, \mathrm{Ar}$ ), $123.9\left(\mathrm{~d},{ }^{2} J_{\mathrm{PC}}=6.4 \mathrm{~Hz}, 1 \mathrm{C}, \mathrm{Ar}\right), 75.4\left(\mathrm{~d},{ }^{2} J_{\mathrm{PC}}=9.9 \mathrm{~Hz}, 1 \mathrm{C}\right.$, $\left.\mathrm{C}\left(\mathrm{CH}_{3}\right)-\mathrm{CH}_{2}\right), 31.6$ (d, $\left.{ }^{3} J_{\mathrm{PC}}=2.3 \mathrm{~Hz}, 1 \mathrm{C}, \underline{\mathrm{C}}\left(\mathrm{CH}_{3}\right)_{3}-\mathrm{CH}_{2}\right), 26.5$ $\left(3 \mathrm{C}, \mathrm{C}\left(\mathrm{CH}_{3}\right)_{3}-\mathrm{CH}_{2}\right), 21.0\left(1 \mathrm{C}, \mathrm{Ar}-\mathrm{CH}_{3}\right) .{ }^{31} \mathbf{P}$ NMR (162 MHz, $\left.295 \mathrm{~K}, \mathrm{CDCl}_{3}\right): \delta / \mathrm{ppm} 123.6\left(\mathrm{t},{ }^{3} J_{\mathrm{PH}}=6.1 \mathrm{~Hz}, 1 \mathrm{P}\right)$. IR $\nu_{\max }$ $\left(\mathrm{cm}^{-1}\right)$ : $1456(\mathrm{~m}), 1364$ (sh), 1258 (w), $1217(\mathrm{w}), 1117(\mathrm{w}), 972$ (s), $789(\mathrm{~m}), 727(\mathrm{~m})$ and $687(\mathrm{sh})$. HRMS $\left(\mathrm{EI}^{+}\right) \mathrm{m} / \mathrm{z}$ calculated for $[\mathrm{M}]^{+}\left[\mathrm{C}_{12} \mathrm{H}_{17} \mathrm{OPS}_{2}\right]^{+}: 272.0458$, found: 272.0452 .

General procedure 4. To a solution of catechol (1.0 equiv.) dissolved in toluene $(40 \mathrm{~mL})$ and cooled to $0{ }^{\circ} \mathrm{C}$, phosphorus (III) chloride (1.2 equiv.) or phosphorus(III) bromide (1.2 equiv.) and triethylamine (2.4 equiv.) were added dropwise. The reaction immediately turned yellow and was left to stir at ambient temperature for 24 hours. The solution was filtered via filter canula to a new Schlenk tube to remove the ammonium salt generated, after which the solvent was removed in vacuo to give a yellow oil. ${ }^{31} \mathrm{P}$ NMR spectroscopy revealed that this oil contained a mixture of both product and an unidentified side product. Therefore, the oil was subjected to an air sensitive distillation, in which the pure product distils with heating and under vacuum ( 5 mbar) to give the product as a colourless oil.

2-Chlorobenzo-1,3,2-dioxaphosphole (7a). Compound 7a was synthesised according to general procedure 4 using phosphorus (III) chloride (3.0 mL, $34.9 \mathrm{mmol}, 1.2$ equiv.), catechol (3.20 g, $29.1 \mathrm{mmol}, 1.0$ equiv.) and triethylamine $(9.7 \mathrm{~mL}, 69.8 \mathrm{mmol}$, 2.4 equiv.). Distils at $44-52{ }^{\circ} \mathrm{C}$ under vacuum (5 mbar). Yield: $1.84 \mathrm{~g}, 10.5 \mathrm{mmol}, 36 \%$. ${ }^{\mathbf{1}} \mathbf{H}$ NMR $\left(500 \mathrm{MHz}, 295 \mathrm{~K}, \mathrm{CDCl}_{3}\right)$ : $\delta /$ ppm 7.19-7.17 (m, 2H, Ar-H), 7.07-7.05 (m, 2H, Ar-H). ${ }^{13} \mathbf{C}\left\{{ }^{1} \mathbf{H}\right\}$ NMR $\left(126 \mathrm{MHz}, 295 \mathrm{~K}, \mathrm{CDCl}_{3}\right): \delta / \mathrm{ppm} 144.4\left(\mathrm{~d},{ }^{2} J_{\mathrm{PC}}=\right.$ $7.5 \mathrm{~Hz}, 2 \mathrm{C}, \mathrm{Ar}$ ), 124.5 (2C, Ar), 114.2 (d, $\left.{ }^{3} J_{\mathrm{PC}}=0.9 \mathrm{~Hz}, 2 \mathrm{C}, \mathrm{Ar}\right)$. ${ }^{31} \mathbf{P}\left\{{ }^{1} \mathbf{H}\right\}$ NMR $\left(202 \mathrm{MHz}, 295 \mathrm{~K}, \mathrm{CDCl}_{3}\right): \delta / p p m 173.6$ (s, 1P). IR $\nu_{\max }\left(\mathrm{cm}^{-1}\right): 1470(\mathrm{~s}), 1327(\mathrm{w}), 1217(\mathrm{~s}), 1092(\mathrm{w}), 1009(\mathrm{w})$, 893 (s), 739 (s), 716 (sh) and 617 (m). HRMS (EI ${ }^{+}$) m/z calculated for $[\mathrm{M}]^{+}\left[\mathrm{C}_{6} \mathrm{H}_{4} \mathrm{ClO}_{2} \mathrm{P}\right]^{+}: 173.9637$, found: 173.9640 .

2-Bromobenzo-1,3,2-dioxaphosphole (7b). Compound $7 \mathbf{b}$ was synthesised according to general procedure 4 using phosphorus(III) bromide (1.30 mL, $13.9 \mathrm{mmol}, 1.2$ equiv.), catechol (1.27 g, $11.6 \mathrm{mmol}, 1.0$ equiv.) and triethylamine $(3.9 \mathrm{~mL}$, $27.8 \mathrm{mmol}, 2.4$ equiv.). Distils at $60-62{ }^{\circ} \mathrm{C}$ under vacuum (5 mbar). Yield: $1.04 \mathrm{~g}, 4.76 \mathrm{mmol}, 41 \% .{ }^{1} \mathbf{H}$ NMR $(500 \mathrm{MHz}$, $\left.295 \mathrm{~K}, \mathrm{CDCl}_{3}\right): \delta / \mathrm{ppm} 7.31\left(\mathrm{ddd},{ }^{3} J_{\mathrm{HH}}=5.9 \mathrm{~Hz},{ }^{4} J_{\mathrm{HH}}=3.4 \mathrm{~Hz}\right.$, $\left.{ }^{4} J_{\mathrm{PH}}=0.8 \mathrm{~Hz}, 2 \mathrm{H}, \mathrm{Ar}-\mathrm{H}\right), 7.19\left(\mathrm{dd},{ }^{3} J_{\mathrm{HH}}=5.9 \mathrm{~Hz},{ }^{4} J_{\mathrm{HH}}=3.4 \mathrm{~Hz}\right.$, $2 \mathrm{H}, \mathrm{Ar}-\mathrm{H}) .{ }^{13} \mathbf{C}\left\{{ }^{1} \mathbf{H}\right\}$ NMR $\left(126 \mathrm{MHz}, 295 \mathrm{~K}, \mathrm{CDCl}_{3}\right): \delta / \mathrm{ppm} 144.8$ $\left(\mathrm{d},{ }^{2} J_{\mathrm{PC}}=7.5 \mathrm{~Hz}, 2 \mathrm{C}, \mathrm{Ar}\right), 124.7$ (2C, Ar), 114.4 (d, ${ }^{3} J_{\mathrm{PC}}=1.0 \mathrm{~Hz}$, 2C, Ar). ${ }^{31} \mathbf{P}\left\{{ }^{1} \mathbf{H}\right\}$ NMR (202 MHz, $295 \mathrm{~K}, \mathrm{CDCl}_{3}$ ): $\delta / \mathrm{ppm} 195.3$ (s, 1P). IR $\nu_{\max }\left(\mathrm{cm}^{-1}\right): 1497$ (s), 1422 (sh), 1169 (m, br), $1098(\mathrm{~m})$, $984(\mathrm{~m}), 937(\mathrm{~m}), 826(\mathrm{~m})$ and $748(\mathrm{~m})$. HRMS $\left(\mathrm{EI}^{+}\right) \mathrm{m} / \mathrm{z}$ calculated for $[\mathrm{M}]^{+}\left[\mathrm{C}_{6} \mathrm{H}_{4} \mathrm{BrO}_{2} \mathrm{P}\right]^{+}$: 217.9132, found: 217.9135 .

General procedure 5. To a solution of $N, N^{\prime}$-diisopropylbenzene-1,2-diamine $^{29}$ (1.0 equiv.) dissolved in toluene
(40 mL) and cooled to $0{ }^{\circ} \mathrm{C}$, phosphorus(III) chloride (1.2 equiv.) or phosphorus(III) bromide (1.2 equiv.) and triethylamine (2.4 equiv.) were added dropwise. The reaction turned yellow and was allowed to stir at ambient temperature for 24 hours. The solution was filtered via filter canula to a new Schlenk tube to remove the ammonium salt generated, after which the solvent was removed in vacuo to give a powder. The powder was washed with pentane $(3 \times 2 \mathrm{~mL})$ and again dried in vacuo to give the pure product as a solid powder.

2-Chlorobenzo-1,3,2-diazaphosphole (8a). Compound 8a was synthesised according to general procedure 5 using phosphorus (III) chloride ( $0.35 \mathrm{~mL}, 4.0 \mathrm{mmol}, 1.2$ equiv.), $N, N^{\prime}$-diisopropylbenzene-1,2-diamine (640 mg, $3.33 \mathrm{mmol}, 1.0$ equiv.), and triethyl amine $(1.11 \mathrm{~mL}, 8.0 \mathrm{mmol}, 2.4$ equiv.). Product is a yellow powder. Yield: $692 \mathrm{mg}, 2.70 \mathrm{mmol}, 81 \%$. ${ }^{\mathbf{1}} \mathbf{H} \mathbf{~ N M R}$ (400 MHz, $295 \mathrm{~K}, \mathrm{CDCl}_{3}$ ): $\delta / \operatorname{ppm} 7.08$ (s, 4H, Ar-H), 4.32 (sept, $\left.{ }^{3} J_{\mathrm{HH}}=6.6 \mathrm{~Hz}, 2 \mathrm{H}, \mathrm{CH}\left(\mathrm{CH}_{3}\right)_{2}\right), 1.69\left(\mathrm{dd},{ }^{3} J_{\mathrm{HH}}=6.6 \mathrm{~Hz},{ }^{4} J_{\mathrm{PH}}=\right.$ $\left.1.0 \mathrm{~Hz}, 12 \mathrm{H}, \mathrm{CH}\left(\mathrm{CH}_{3}\right)_{2}\right) .{ }^{13} \mathbf{C}\left\{{ }^{1} \mathbf{H}\right\}$ NMR (101 MHz, $295 \mathrm{~K}$, $\mathrm{CDCl}_{3}$ ): $\delta / \mathrm{ppm} 136.9$ (d, $\left.{ }^{2} J_{\mathrm{PC}}=10.5 \mathrm{~Hz}, 2 \mathrm{C}, \mathrm{Ar}\right), 121.3(2 \mathrm{C}, \mathrm{Ar}$ ), $111.6\left(\mathrm{~d},{ }^{3} J_{\mathrm{PC}}=1.6 \mathrm{~Hz}, 2 \mathrm{C}, \mathrm{Ar}\right), 48.1\left(\mathrm{~d},{ }^{2} J_{\mathrm{PC}}=12.7 \mathrm{~Hz}, 2 \mathrm{C}, \underline{\mathrm{CH}}\right.$ $\left.\left(\mathrm{CH}_{3}\right)_{2}\right), 22.3\left(4 \mathrm{C}, \mathrm{CH}\left(\mathrm{CH}_{3}\right)_{2}\right) .{ }^{31} \mathbf{P}\left\{{ }^{1} \mathbf{H}\right\}$ NMR $(162 \mathrm{MHz}, 295 \mathrm{~K}$, $\left.\mathrm{CDCl}_{3}\right): \delta / \mathrm{ppm} 147.1(\mathrm{~s}, 1 \mathrm{P})$. Values in agreement with literature. $^{29}$

2-Bromobenzo-1,3,2-diazaphosphole (8b). Compound $8 \mathrm{~b}$ was synthesised according to general procedure $\mathbf{5}$ using phosphorus(III) bromide (0.11 mL, $1.19 \mathrm{mmol}, 1.2$ equiv.), $N, N^{\prime}$-diisopropylbenzene-1,2-diamine (191 mg, $0.99 \mathrm{mmol}$, 1.0 equiv.), and triethyl amine (0.3 mL, $2.38 \mathrm{mmol}, 2.4$ equiv.). Product is an orange powder. Yield: $227 \mathrm{mg}, 0.75 \mathrm{mmol}, 76 \%$. ${ }^{1} \mathbf{H}$ NMR $\left(400 \mathrm{MHz}, 295 \mathrm{~K}, \mathrm{CDCl}_{3}\right): \delta / \mathrm{ppm} 7.18-7.17(\mathrm{~m}, 4 \mathrm{H}$, $\mathrm{Ar}-\mathrm{H}$ ), 4.44 (sept, $\left.{ }^{3} \mathrm{~J}_{\mathrm{HH}}=6.6 \mathrm{~Hz}, 2 \mathrm{H}, \mathrm{CH}\left(\mathrm{CH}_{3}\right)_{2}\right), 1.76$ (dd, $\left.{ }^{3} J_{\mathrm{HH}}=6.6 \mathrm{~Hz},{ }^{4} J_{\mathrm{PH}}=1.0 \mathrm{~Hz}, 12 \mathrm{H}, \mathrm{CH}\left(\mathrm{CH}_{3}\right)_{2}\right) .{ }^{13} \mathbf{C}\left\{{ }^{1} \mathbf{H}\right\} \mathbf{N M R}$ $\left(101 \mathrm{MHz}, 295 \mathrm{~K}, \mathrm{CDCl}_{3}\right): \delta / \mathrm{ppm} 137.2\left(\mathrm{~d},{ }^{2} J_{\mathrm{PC}}=10.2 \mathrm{~Hz}\right.$, 2C, Ar), 122.3 (2C, Ar), 112.4 (d, $\left.{ }^{3} J_{\mathrm{PC}}=1.6 \mathrm{~Hz}, 2 \mathrm{C}, \mathrm{Ar}\right), 49.0$ (d, $\left.{ }^{2} J_{\mathrm{PC}}=11.8 \mathrm{~Hz}, 2 \mathrm{C}, \underline{\mathrm{CH}}\left(\mathrm{CH}_{3}\right)_{2}\right), 21.8\left(\mathrm{~d},{ }^{3} J_{\mathrm{PC}}=1.6 \mathrm{~Hz}, 4 \mathrm{C}\right.$, $\left.\mathrm{CH}\left(\mathrm{CH}_{3}\right)_{2}\right) .{ }^{31} \mathbf{P}\left\{{ }^{1} \mathbf{H}\right\}$ NMR $\left(162 \mathrm{MHz}, 295 \mathrm{~K}, \mathrm{CDCl}_{3}\right): \delta / \mathrm{ppm}$ $169.2(\mathrm{~s}, 1 \mathrm{P})$. IR $\nu_{\max }\left(\mathrm{cm}^{-1}\right): 1477(\mathrm{~m}), 1369(\mathrm{~m}), 1288(\mathrm{w})$, $1159(\mathrm{~m}), 1007(\mathrm{~m}), 932(\mathrm{~m})$ and $752(\mathrm{~m})$. HRMS $\left(\mathrm{EI}^{+}\right) \mathrm{m} / \mathrm{z}$ calculated for $[\mathrm{M}]^{+}\left[\mathrm{C}_{12} \mathrm{H}_{18} \mathrm{BrN}_{2} \mathrm{P}\right]^{+}$: 300.0391 , found: 300.0384 . Melting point $100-106^{\circ} \mathrm{C}$.

General procedure 6. To a solution of 2-chlorobenzo-1,3,2dioxaphosphole (1.0 equiv.) in $\mathrm{CH}_{2} \mathrm{Cl}_{2}(5 \mathrm{~mL})$, benzyl alcohol (1.0 equiv.) or neopentyl alcohol (1.0 equiv.) and triethyl amine (1.0 equiv.) were added dropwise. The reaction was allowed to stir at ambient temperature for 24 hours, after which the solvent was removed in vacuo. Toluene $(2 \mathrm{~mL})$ was subsequently added and the resulting solution was filtered through a plug of Celite to remove traces of ammonium salt, after which the solvent was again removed in vacuo to give the product as an oil.

2-(Benzyloxy)benzo-1,3,2-dioxaphosphole (9a). Compound 9a was synthesised according to general procedure 6 using 2-chlorobenzo-1,3,2-dioxaphosphole (206 mg, $1.18 \mathrm{mmol}$, 1.0 equiv.), benzyl alcohol (128 mg, $1.18 \mathrm{mmol}, 1.0$ equiv.), and triethylamine (119 mg, $1.18 \mathrm{mmol}, 1.0$ equiv.). Product is a dark yellow/orange oil. Yield: $198 \mathrm{mg}, 0.80 \mathrm{mmol}, 68 \%$. 
${ }^{1} \mathbf{H}$ NMR (400 MHz, $\left.295 \mathrm{~K}, \mathrm{CDCl}_{3}\right): \delta / \mathrm{ppm} 7.32-7.30(\mathrm{~m}, 3 \mathrm{H}$, $\mathrm{Ar}-\mathrm{H}), 7.21-7.19$ (m, 2H, Ar-H), 7.12-7.10 (m, 2H, Ar-H), 7.02-7.00 (m, 2H, Ar-H), $4.60\left(\mathrm{~d},{ }^{3} J_{\mathrm{PH}}=6.9 \mathrm{~Hz}, 2 \mathrm{H}, \mathrm{OCH}_{2}\right)$. ${ }^{13} \mathbf{C}\left\{{ }^{1} \mathbf{H}\right\}$ NMR $\left(101 \mathrm{MHz}, 295 \mathrm{~K}, \mathrm{CDCl}_{3}\right): \delta / \mathrm{ppm} 146.0\left(\mathrm{~d},{ }^{2} J_{\mathrm{PC}}=\right.$ $7.6 \mathrm{~Hz}, 2 \mathrm{C}, \mathrm{Ar}$ ), 136.7 (d, ${ }^{3} J_{\mathrm{PC}}=2.9 \mathrm{~Hz}, 2 \mathrm{C}, \mathrm{Ar}$ ), 128.7 (Ar), 128.4 (Ar), 127.7 (Ar), 123.0 (Ar), $112.2(\mathrm{Ar}), 65.9$ (d, ${ }^{2} J_{\mathrm{PC}}=2.0 \mathrm{~Hz}, 1 \mathrm{C}$, $\left.\mathrm{C}\left(\mathrm{CH}_{3}\right)_{3}-\mathrm{CH} 2\right) .{ }^{31} \mathbf{P}\left\{{ }^{1} \mathbf{H}\right\}$ NMR $\left(162 \mathrm{MHz}, 295 \mathrm{~K}, \mathrm{CDCl}_{3}\right): \delta / \mathrm{ppm}$ 126.9 (s, 1P). IR $\nu_{\max }\left(\mathrm{cm}^{-1}\right): 1474(\mathrm{~s}), 1373$ (w), 1229 (s), 980 (m), $916(\mathrm{w}), 824$ (s), $729(\mathrm{~s}), 692$ (s) and $625(\mathrm{~m})$. HRMS $\left(\mathrm{EI}^{+}\right)$ $m / z$ calculated for $[\mathrm{M}]^{+}\left[\mathrm{C}_{13} \mathrm{H}_{11} \mathrm{O}_{3} \mathrm{P}\right]^{+}: 246.0446$, found: 246.0441 .

2-(Neopentyloxy)benzo-1,3,2-dioxaphosphole (9b). Compound 9b was synthesised according to general procedure 6 using 2-chlorobenzo-1,3,2-dioxaphosphole (203 mg, $1.16 \mathrm{mmol}$, 1.0 equiv.), neopentyl alcohol (103 mg, $1.16 \mathrm{mmol}, 1.0$ equiv.) and triethyl amine (117 mg, $1.16 \mathrm{mmol}, 1.0$ equiv.). Product is a faint orange/yellow coloured oil. Yield: $168 \mathrm{mg}, 0.74 \mathrm{mmol}$, 64\%. ${ }^{1} \mathbf{H}$ NMR $\left(400 \mathrm{MHz}, 295 \mathrm{~K}, \mathrm{CDCl}_{3}\right): \delta / \mathrm{ppm} 7.08-7.05(\mathrm{~m}$, $2 \mathrm{H}, \mathrm{Ar}-\mathrm{H}), 6.99-6.96(\mathrm{~m}, 2 \mathrm{H}, \mathrm{Ar}-\mathrm{H}), 3.21\left(\mathrm{~d},{ }^{3} J_{\mathrm{PH}}=6.5 \mathrm{~Hz}, 2 \mathrm{H}\right.$, $\left.\mathrm{OCH}_{2}\right), 0.83\left(\mathrm{~s}, 9 \mathrm{H}, \mathrm{CH}_{2} \mathrm{CH}_{3}\right) .{ }^{13} \mathbf{C}\left\{{ }^{1} \mathbf{H}\right\}$ NMR $(101 \mathrm{MHz}, 295 \mathrm{~K}$, $\mathrm{CDCl}_{3}$ ): $\delta / \mathrm{ppm} 146.0$ (d, $\left.{ }^{2} \bar{J}_{\mathrm{PC}}=7.7 \mathrm{~Hz}, 2 \mathrm{C}, \mathrm{Ar}\right), 122.7$ (2C, Ar), 111.9 (2C, Ar), 73.6 (d, $\left.{ }^{2} J_{\mathrm{PC}}=2.0 \mathrm{~Hz}, 1 \mathrm{C}, \mathrm{C}\left(\mathrm{CH}_{3}\right)_{3}-\mathrm{CH}_{2}\right), 31.9$ (d, $\left.{ }^{3} J_{\mathrm{PC}}=2.7 \mathrm{~Hz}, 1 \mathrm{C}, \underline{\mathrm{C}}\left(\mathrm{CH}_{3}\right)_{3}-\mathrm{CH}_{2}\right), 26.2\left(3 \mathrm{C}, \underline{\mathrm{C}}\left(\mathrm{CH}_{3}\right)_{3}-\mathrm{CH}_{2}\right)$. ${ }^{31} \mathbf{P}\left\{{ }^{1} \mathbf{H}\right\}$ NMR (162 MHz, $\left.295 \mathrm{~K}, \mathrm{CDCl}_{3}\right): \delta / \mathrm{ppm} 127.4(\mathrm{~s}, 1 \mathrm{P})$. IR $\nu_{\max }\left(\mathrm{cm}^{-1}\right): 1476(\mathrm{~s}), 1366(\mathrm{w}), 1333(\mathrm{w}), 1231(\mathrm{~s}), 1003(\mathrm{~s})$, $824(\mathrm{~s}), 739(\mathrm{~m}), 698(\mathrm{~m}), 623(\mathrm{~m})$ and $536(\mathrm{w}) . \mathbf{H R M S}\left(\mathrm{EI}^{+}\right) \mathrm{m} / \mathrm{z}$ calculated for $[\mathrm{M}]^{+}\left[\mathrm{C}_{11} \mathrm{H}_{15} \mathrm{O}_{3} \mathrm{P}\right]^{+}: 226.0759$, found: 226.0756 .

1,3-Diisopropyl-benzodiphosphenium triflate (10). To a solution of 2-chloro-1,3-diisopropyl-benzodiazaphosphole (70 mg, $0.27 \mathrm{mmol}, 1.0$ equiv.) dissolved in $\mathrm{CH}_{2} \mathrm{Cl}_{2}(5 \mathrm{~mL})$, trimethylsilyl trifluoromethanesulfonate ( $73 \mathrm{mg}, 0.33 \mathrm{mmol}, 1.2$ equiv.) was added dropwise. The solution immediately turned golden yellow and was allowed to stir for two hours at ambient temperature. Afterwards, the solvent was removed in vacuo and washed with pentane $(3 \times 2 \mathrm{~mL})$ and again dried in vacuo to give the pure product 1,3-diisopropyl-benzodiphosphenium triflate as a yellow powder. Yield: $88 \mathrm{mg}, 0.24 \mathrm{mmol}, 87 \%$. ${ }^{1} \mathbf{H}$ NMR $\left(400 \mathrm{MHz}, 295 \mathrm{~K}, \mathrm{CDCl}_{3}\right): \delta / \mathrm{ppm} 7.71-7.69(\mathrm{~m}, 2 \mathrm{H}$, $\mathrm{Ar}-\mathrm{H}$ ), 7.63-7.60 (m, 2H, Ar-H), 4.98 (sept, ${ }^{3} \mathrm{~J}_{\mathrm{HH}}=6.6 \mathrm{~Hz}, 2 \mathrm{H}$, $\left.\mathrm{C} \underline{\mathrm{H}}\left(\mathrm{CH}_{3}\right)_{2}\right), 1.87\left(\mathrm{dd},{ }^{3} J_{\mathrm{HH}}=6.6 \mathrm{~Hz},{ }^{4} J_{\mathrm{PH}}=1.3 \mathrm{~Hz}, 12 \mathrm{H}, \mathrm{CH}\right.$ $\left.\left(\mathrm{CH}_{3}\right)_{2}\right) \cdot{ }^{13} \mathbf{C}\left\{{ }^{1} \mathbf{H}\right\}$ NMR $\left(101 \mathrm{MHz}, 295 \mathrm{~K}, \mathrm{CDCl}_{3}\right): \delta / \mathrm{ppm} 138.6$ $\left(\mathrm{d},{ }^{2} \mathrm{~J}_{\mathrm{PC}}=6.0 \mathrm{~Hz}, 2 \mathrm{C}, \mathrm{Ar}\right), 127.2$ (2C, Ar), 114.3 (2C, Ar), 52.6 (d, $\left.{ }^{2} J_{\mathrm{PC}}=10.8 \mathrm{~Hz}, 2 \mathrm{C}, \underline{\mathrm{CH}}\left(\mathrm{CH}_{3}\right)_{2}\right), 23.9\left(4 \mathrm{C}, \mathrm{CH}\left(\mathrm{CH}_{3}\right)_{2}\right) .{ }^{31} \mathbf{P}\left\{{ }^{1} \mathbf{H}\right\}$ NMR (162 MHz, $\left.295 \mathrm{~K}, \mathrm{CDCl}_{3}\right): \delta / \mathrm{ppm} 216.0$ (s, 1P). ${ }^{19} \mathbf{F}\left\{{ }^{\mathbf{1}} \mathbf{H}\right\}$ NMR $\left(376 \mathrm{MHz}, 295 \mathrm{~K}, \mathrm{CDCl}_{3}\right): \delta / \mathrm{ppm}-78.4\left(\mathrm{~s}, 3 \mathrm{~F}, \mathrm{O}_{3} \mathrm{SCF}_{3}{ }^{-}\right)$. Values in agreement with literature. ${ }^{29}$

\section{Polymerisation of THF}

In a typical reaction THF (50 mL, $616 \mathrm{mmol}, 1369$ equiv.) was added to a sample of $3 \mathbf{b}(0.018 \mathrm{~g}, 0.45 \mathrm{mmol}, 1.0$ equiv.) (equivalent to $9.06 \mathrm{mmol} \mathrm{L}^{-1}$ or $\left.1: 2469 \mathrm{w} / \mathrm{w}\right)$. The solution immediately turned colourless and the progress of the polymerisation was followed by ${ }^{1} \mathrm{H}$ NMR spectroscopy.

\section{Oxidation reactions with dimer 5}

Reaction of 5 with $\mathbf{S O}_{2} \mathbf{C l}_{2} \cdot 0.35 \mathrm{~mL}$ (0.12 mmol, 1.1 equiv.)

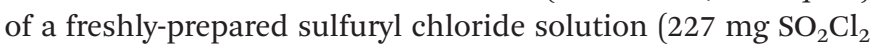

in $5 \mathrm{~mL} \mathrm{CH} \mathrm{Cl}_{2}$ ) was added dropwise to a solution of $3(40 \mathrm{mg}$, $0.11 \mathrm{mmol}, 1.0$ equiv.) in toluene $(5 \mathrm{~mL})$ at $0{ }^{\circ} \mathrm{C}$. The reaction mixture was stirred at $0{ }^{\circ} \mathrm{C}$ for $2 \mathrm{~h}$ and the solvent removed in vacuo. Storage of the resultant colourless oil at $-20{ }^{\circ} \mathrm{C}$ afforded colourless crystals of 1a. Yield: $42 \mathrm{mg}, 0.19 \mathrm{mmol}$, $88 \% .{ }^{1} \mathrm{H}$ NMR $\left(300 \mathrm{MHz}, 295 \mathrm{~K}, \mathrm{C}_{6} \mathrm{D}_{6}\right): \delta / \mathrm{ppm} 6.98\left(\mathrm{~d},{ }^{3} J_{\mathrm{HH}}=\right.$ $8.1 \mathrm{~Hz}, 1 \mathrm{H}, \mathrm{Ar}-\mathrm{H}), 6.82(\mathrm{~s}, 1 \mathrm{H}, \mathrm{Ar}-\mathrm{H}), 6.48\left(\mathrm{~d},{ }^{3} J_{\mathrm{HH}}=8.1 \mathrm{~Hz}\right.$, 1H, Ar-H), $1.80\left(\mathrm{~s}, 3 \mathrm{H}, \mathrm{CH}_{3}\right) .{ }^{31} \mathbf{P}\left\{{ }^{1} \mathbf{H}\right\}$ NMR $(202 \mathrm{MHz}, 295 \mathrm{~K}$, $\left.\mathrm{C}_{6} \mathrm{D}_{6}\right): \delta /$ ppm $161.4(\mathrm{~s}, 1 \mathrm{P})$.

Reaction of 5 with $\mathbf{B r}_{2} \cdot 0.88 \mathrm{~mL}$ ( $0.17 \mathrm{mmol}, 1.1$ equiv.) of a freshly-prepared bromine solution (153 $\mathrm{mg} \mathrm{Br}$ in $5 \mathrm{~mL}$ $\mathrm{CH}_{2} \mathrm{Cl}_{2}$ ) was added dropwise to a solution of $3(57 \mathrm{mg}$, $0.15 \mathrm{mmol}, 1.0$ equiv.) in toluene $(5 \mathrm{~mL})$ at $0{ }^{\circ} \mathrm{C}$. The reaction mixture was stirred at $0{ }^{\circ} \mathrm{C}$ for $2 \mathrm{~h}$ and the solvent removed in vacuo to afford a yellow solid. Recrystallisation from $\mathrm{CH}_{2} \mathrm{Cl}_{2}$ afforded yellow crystals of $\mathbf{1 b}$. Yield: $58 \mathrm{mg}, 0.22 \mathrm{mmol}, 70 \%$. ${ }^{1} \mathbf{H}$ NMR $\left(500 \mathrm{MHz}, 295 \mathrm{~K}, \mathrm{C}_{6} \mathrm{D}_{6}\right): \delta / \mathrm{ppm} 7.03\left(\mathrm{~d},{ }^{3} J_{\mathrm{HH}}=8.0 \mathrm{~Hz}\right.$, $1 \mathrm{H}, \mathrm{Ar}-\mathrm{H}), 6.87(\mathrm{~s}, 1 \mathrm{H}, \mathrm{Ar}-\mathrm{H}), 6.55\left(\mathrm{~d},{ }^{3} J_{\mathrm{HH}}=8.0 \mathrm{~Hz}, 1 \mathrm{H}, \mathrm{Ar}-\right.$ $\mathrm{H}), 1.86$ (s, 3H, $\left.\mathrm{CH}_{3}\right) .{ }^{31} \mathbf{P}\left\{{ }^{1} \mathbf{H}\right\}$ NMR $\left(202 \mathrm{MHz}, 295 \mathrm{~K}, \mathrm{C}_{6} \mathrm{D}_{6}\right): \delta /$ ppm $163.6(\mathrm{~s}, 1 \mathrm{P})$. Elemental analysis Found (Calc. for $\mathrm{C}_{7} \mathrm{H}_{6} \mathrm{BrPS}_{2}$ ): $\mathrm{C}=31.4 \%$ (31.7); $\mathrm{H}=2.4 \%$ (2.3).

Reaction of 5 with $\mathbf{I}_{2}$. A solution of $\mathrm{I}_{2}(33 \mathrm{mg}, 0.13 \mathrm{mmol}, 1.0$ equiv.) in toluene $(2 \mathrm{~mL})$ was added dropwise to a solution of 3 (48 mg, $0.13 \mathrm{mmol}, 1.0$ equiv.) in toluene $(3 \mathrm{~mL})$ at $0{ }^{\circ} \mathrm{C}$. The reaction mixture was stirred at $0{ }^{\circ} \mathrm{C}$ for 2.5 hours and the solvent removed in vacuo to give a yellow solid. Recrystallisation from $\mathrm{CH}_{2} \mathrm{Cl}_{2}$ afforded yellow crystals of 1c. Yield: $55 \mathrm{mg}, 0.18 \mathrm{mmol}, 68 \% .{ }^{1} \mathbf{H}$ NMR $(500 \mathrm{MHz}, 295 \mathrm{~K}$, $\left.\mathrm{C}_{6} \mathrm{D}_{6}\right): \delta / \mathrm{ppm} 6.95\left(\mathrm{~d},{ }^{3} J_{\mathrm{HH}}=8.0 \mathrm{~Hz}, 1 \mathrm{H}, \mathrm{Ar}-\mathrm{H}\right), 6.79(\mathrm{~s}, 1 \mathrm{H}$, $\mathrm{Ar}-\mathrm{H}), 6.48\left(\mathrm{~d},{ }^{3} J_{\mathrm{HH}}=8.0 \mathrm{~Hz}, 1 \mathrm{H}, \mathrm{Ar}-\mathrm{H}\right), 1.79\left(\mathrm{~s}, 3 \mathrm{H}, \mathrm{CH}_{3}\right)$. ${ }^{31} \mathbf{P}\left\{{ }^{1} \mathbf{H}\right\}$ NMR (202 MHz, $\left.295 \mathrm{~K}, \mathrm{C}_{6} \mathrm{D}_{6}\right)$ : $\delta /$ ppm 155.4 (s, 1P).

\section{General experimental for hydroboration catalysis}

In a glovebox under a dinitrogen atmosphere, three separate vials were charged with the phosphorus catalyst $(10,5,2$ or $1 \mathrm{~mol} \%$ ), aldehyde (0.1 mmol, 1 equiv.), and HBpin $(12.8 \mathrm{mg}$, $0.1 \mathrm{mmol}, 1$ equiv.). By syringe, solvent $(0.6 \mathrm{~mL})$ was added to the vial containing HBpin and then mixed between the three vials at least twice. The solution was transferred to a J. Young NMR tube and multinuclear NMR spectra were acquired at 2 h, 6 h, 12 h and 24 hours. Product conversion was calculated from the in situ ${ }^{1} \mathrm{H}$ NMR spectrum by integrating the aldehyde signal and new resonance resulting from the hydride from HBpin.

\section{Characterisation of hydroborated products}

4,4,5,5-Tetramethyl-2-((4-(trifluoromethyl)benzyl)oxy)-1,3,2dioxaborolane (11a). ${ }^{1} \mathbf{H}$ NMR $\left(500 \mathrm{MHz}, 295 \mathrm{~K}, \mathrm{CDCl}_{3}\right): \delta / \mathrm{ppm}$ $7.57\left(\mathrm{~d},{ }^{3} J_{\mathrm{HH}}=8.3 \mathrm{~Hz}, 2 \mathrm{H}, \mathrm{Ar}-\mathrm{H}\right), 7.44\left(\mathrm{dd},{ }^{3} J_{\mathrm{HH}}=8.3 \mathrm{~Hz},{ }^{4} J_{\mathrm{HF}}=\right.$ $0.7 \mathrm{~Hz}, 2 \mathrm{H}, \mathrm{Ar}-\mathrm{H}), 4.97\left(\mathrm{~s}, 2 \mathrm{H}, \mathrm{CH}_{2}\right), 1.25\left(\mathrm{~s}, 12 \mathrm{H}, \mathrm{CH}_{3}\right)$. ${ }^{11}$ B NMR (160 MHz, $295 \mathrm{~K}, \mathrm{CDCl}_{3}$ ): $\delta / \mathrm{ppm} 22.4$ (s, Bpin). ${ }^{19} \mathbf{F}\left\{{ }^{1} \mathbf{H}\right\}$ NMR $\left(471 \mathrm{MHz}, 295 \mathrm{~K}, \mathrm{CDCl}_{3}\right): \delta / \mathrm{ppm}-62.5(\mathrm{~s}, 3 \mathrm{~F}$, $\left.\mathrm{Ar}-\mathrm{CF}_{3}\right)$. Values in agreement with literature. ${ }^{22}$

2-((4-Fluorobenzyl)oxy)-4,4,5,5-tetramethyl-1,3,2-dioxaborolane (11b). ${ }^{1} \mathbf{H}$ NMR $\left(500 \mathrm{MHz}, 295 \mathrm{~K}, \mathrm{CDCl}_{3}\right): \delta / \mathrm{ppm} 7.33-7.29(\mathrm{~m}$, 2H, Ar-H), 7.01 (ov dd, ${ }^{3} J_{\mathrm{HH}, \mathrm{HF}}, 8.8 \mathrm{~Hz}, 2 \mathrm{H}, \mathrm{Ar}-\mathrm{H}$ ), 4.87 (s, 2H, 
$\left.\mathrm{CH}_{2}\right), 1.26\left(\mathrm{~s}, 12 \mathrm{H}, \mathrm{CH}_{3}\right) \cdot{ }^{11} \mathbf{B}$ NMR $\left(128 \mathrm{MHz}, 295 \mathrm{~K}, \mathrm{CDCl}_{3}\right)$ : $\delta /$ ppm 22.3 (s, Bpin). ${ }^{19} \mathbf{F}\left\{{ }^{1} \mathbf{H}\right\}$ NMR (376 MHz, $295 \mathrm{~K}, \mathrm{CDCl}_{3}$ ): $\delta / \mathrm{ppm}-115.3(\mathrm{~s}, 1 \mathrm{~F}, \mathrm{Ar}-\mathrm{F})$. Values in agreement with literature. $^{22}$

2-((3-Fluorobenzyl)oxy)-4,4,5,5-tetramethyl-1,3,2-dioxaborolane (11c). ${ }^{1} \mathbf{H}$ NMR $\left(400 \mathrm{MHz}, 295 \mathrm{~K}, \mathrm{CDCl}_{3}\right): \delta / \mathrm{ppm} 7.31-7.27(\mathrm{~m}$, 2H, Ar-H), 7.11-7.05 (m, 2H, Ar-H), 6.97-6.92 (m, 1H, Ar-H), $4.91\left(\mathrm{~s}, 2 \mathrm{H}, \mathrm{CH}_{2}\right), 1.27\left(\mathrm{~s}, 12 \mathrm{H}, \mathrm{CH}_{3}\right) .{ }^{11} \mathbf{B}$ NMR $(128 \mathrm{MHz}$, $295 \mathrm{~K}, \mathrm{CDCl}_{3}$ ): $\delta /$ ppm 22.3 (s, Bpin). ${ }^{19} \mathbf{F}\left\{{ }^{1} \mathbf{H}\right\}$ NMR $(376 \mathrm{MHz}$, $\left.295 \mathrm{~K}, \mathrm{CDCl}_{3}\right): \delta / \mathrm{ppm}-113.4(\mathrm{~s}, 1 \mathrm{~F}, \mathrm{Ar}-\mathrm{F})$. Values in agreement with literature. ${ }^{22}$

2-((2-Fluorobenzyl)oxy)-4,4,5,5-tetramethyl-1,3,2-dioxaborolane (11d). ${ }^{1} \mathbf{H}$ NMR $\left(500 \mathrm{MHz}, 295 \mathrm{~K}, \mathrm{CDCl}_{3}\right): \delta / \mathrm{ppm} 7.47-7.42(\mathrm{~m}$, $1 \mathrm{H}, \mathrm{Ar}-\mathrm{H}), 7.25-7.22(\mathrm{~m}, 1 \mathrm{H}, \mathrm{Ar}-\mathrm{H}), 7.12\left(\mathrm{td},{ }^{3} J_{\mathrm{HH}}=7.5 \mathrm{~Hz}\right.$, $\left.{ }^{4} J_{\mathrm{HH}}=1.1 \mathrm{~Hz}, 1 \mathrm{H}, \mathrm{Ar}-\mathrm{H}\right), 7.04-6.96(\mathrm{~m}, 1 \mathrm{H}, \mathrm{Ar}-\mathrm{H}), 5.00(\mathrm{~s}, 2 \mathrm{H}$, $\left.\mathrm{CH}_{2}\right), 1.27$ (s, 12H, $\left.\mathrm{CH}_{3}\right) .{ }^{11} \mathbf{B}$ NMR (128 MHz, $\left.295 \mathrm{~K}, \mathrm{CDCl}_{3}\right)$ : $\delta /$ ppm 22.3 (s, Bpin). ${ }^{19} \mathbf{F}\left\{{ }^{1} \mathbf{H}\right\}$ NMR (376 MHz, $295 \mathrm{~K}, \mathrm{CDCl}_{3}$ ): $\delta / \mathrm{ppm}-119.2$ (s, 1F, Ar-F). Values in agreement with literature. ${ }^{22}$

2-((4-Bromobenzyl)oxy)-4,4,5,5-tetramethyl-1,3,2-dioxaborolane (11e). ${ }^{1} \mathrm{H}$ NMR $\left(400 \mathrm{MHz}, 295 \mathrm{~K}, \mathrm{CDCl}_{3}\right): \delta / \mathrm{ppm} 7.45\left(\mathrm{~d},{ }^{3} \mathrm{~J}_{\mathrm{HH}}=\right.$ $8.7 \mathrm{~Hz}, 2 \mathrm{H}, \mathrm{Ar}-\mathrm{H}), 7.22\left(\mathrm{~d},{ }^{3} \mathrm{~J}_{\mathrm{HH}}=8.7 \mathrm{~Hz}, 2 \mathrm{H}, \mathrm{Ar}-\mathrm{H}\right), 4.86$ $\left(\mathrm{s}, 2 \mathrm{H}, \mathrm{CH}_{2}\right), 1.26$ (s, 12H, $\left.\mathrm{CH}_{3}\right) .{ }^{11} \mathbf{B}$ NMR $(128 \mathrm{MHz}, 295 \mathrm{~K}$, $\left.\mathrm{CDCl}_{3}\right): \delta / \mathrm{ppm} 22.3$ (s, Bpin). Values in agreement with literature. $^{22}$

4-(((4,4,5,5-Tetramethyl-1,3,2-dioxaborolan-2-yl)oxy)methyl) benzonitrile (11f). ${ }^{1} \mathrm{H}$ NMR $\left(400 \mathrm{MHz}, 295 \mathrm{~K}, \mathrm{CDCl}_{3}\right): \delta / \mathrm{ppm}$ 7.64-7.60 (m, 2H, Ar-H), 7.45-7.43 (m, 2H, Ar-H), 4.97 (s, 2H, $\left.\mathrm{CH}_{2}\right), 1.26\left(\mathrm{~s}, 12 \mathrm{H}, \mathrm{CH}_{3}\right) .{ }^{11} \mathbf{B}$ NMR (128 MHz, $\left.295 \mathrm{~K}, \mathrm{CDCl}_{3}\right)$ : $\delta /$ ppm 22.4 (s, 1B, Bpin). Values in agreement with literature. ${ }^{22}$

4,4,5,5-Tetramethyl-2-((4-nitrobenzyl)oxy)-1,3,2-dioxaborolane (11g). ${ }^{1} \mathbf{H}$ NMR $\left(500 \mathrm{MHz}, 295 \mathrm{~K}, \mathrm{CDCl}_{3}\right): \delta / \mathrm{ppm} 8.18\left(\mathrm{~d},{ }^{3} J_{\mathrm{HH}}=\right.$ $8.9 \mathrm{~Hz}, 2 \mathrm{H}, \mathrm{Ar}-\mathrm{H}), 7.49\left(\mathrm{~d},{ }^{3} J_{\mathrm{HH}}=8.9 \mathrm{~Hz}, 2 \mathrm{H}, \mathrm{Ar}-\mathrm{H}\right), 5.01(\mathrm{~s}$, $\left.2 \mathrm{H}, \mathrm{CH}_{2}\right), 1.26\left(\mathrm{~s}, 12 \mathrm{H}, \mathrm{CH}_{3}\right) .{ }^{11} \mathbf{B} \mathbf{N M R}(160 \mathrm{MHz}, 295 \mathrm{~K}$, $\left.\mathrm{CDCl}_{3}\right): \delta / \mathrm{ppm} 21.1$ (s, Bpin). Values in agreement with literature. ${ }^{47}$

2-(Benzyloxy)-4,4,5,5-tetramethyl-1,3,2-dioxaborolane (11h). ${ }^{1} \mathbf{H}$ NMR $\left(400 \mathrm{MHz}, 295 \mathrm{~K}, \mathrm{CDCl}_{3}\right): \delta / \mathrm{ppm} 7.26-7.24(\mathrm{~m}, 2 \mathrm{H}$, $\mathrm{Ar}-\mathrm{H}), 7.20-7.18$ (m, 2H, Ar-H), 4.85 (s, 2H, $\left.\mathrm{CH}_{2}\right), 1.18$ (s, 12H, $\mathrm{CH}_{3}$ ). ${ }^{11}$ B NMR (128 MHz, $295 \mathrm{~K}, \mathrm{CDCl}_{3}$ ): $\delta /$ ppm 22.3 (s, Bpin). Values in agreement with literature. ${ }^{22}$

1,4-bis(((4,4,5,5-Tetramethyl-1,3,2-dioxaborolan-2-yl)oxy)methyl) benzene (11i). ${ }^{1} \mathrm{H}$ NMR (400 MHz, $295 \mathrm{~K}, \mathrm{CDCl}_{3}$ ): $\delta / \mathrm{ppm} 7.30$ (s, 4H, Ar-H), 4.90 (s, 4H, $\left.\mathrm{CH}_{2}\right), 1.25$ (s, 24H, $\left.\mathrm{CH}_{3}\right) .{ }^{11} \mathbf{B}$ NMR $\left(128 \mathrm{MHz}, 295 \mathrm{~K}, \mathrm{CDCl}_{3}\right.$ ): $\delta / \mathrm{ppm} 22.3$ (s, Bpin). Values in agreement with literature. ${ }^{22}$

$N, N$-Dimethyl-4-(((4,4,5,5-tetramethyl-1,3,2-dioxaborolan-2-yl) oxy)methyl)aniline (11j). ${ }^{1} \mathbf{H}$ NMR (400 MHz, $\left.295 \mathrm{~K}, \mathrm{CDCl}_{3}\right)$ : $\delta /$ ppm $7.25\left(\mathrm{~d},{ }^{3} J_{\mathrm{HH}}=8.8 \mathrm{~Hz}, 2 \mathrm{H}, \mathrm{Ar}-\mathrm{H}\right), 6.75\left(\mathrm{~d},{ }^{3} J_{\mathrm{HH}}=8.8 \mathrm{~Hz}\right.$, $2 \mathrm{H}, \mathrm{Ar}-\mathrm{H}), 4.82\left(\mathrm{~s}, 2 \mathrm{H}, \mathrm{CH}_{2}\right), 2.95\left(\mathrm{~s}, 6 \mathrm{H}, \mathrm{N}\left(\mathrm{CH}_{3}\right)_{2}\right), 1.26$ $\left(\mathrm{s}, 12 \mathrm{H}, \mathrm{CH}_{3}\right) \cdot{ }^{11} \mathbf{B}$ NMR $\left(128 \mathrm{MHz}, 295 \mathrm{~K}, \mathrm{CDCl}_{3}\right): \delta / \mathrm{ppm} 22.3$ (s, Bpin). Values in agreement with literature. ${ }^{47}$

4,4,5,5-Tetramethyl-2-(naphthalen-2-ylmethoxy)-1,3,2-dioxaborolane (11k). ${ }^{1} \mathbf{H}$ NMR (400 MHz, $295 \mathrm{~K}, \mathrm{CDCl}_{3}$ ): $\delta / \mathrm{ppm} 7.84-7.81$ (m, $4 \mathrm{H}, \mathrm{Ar}-\mathrm{H}), 7.48-7.44(\mathrm{~m}, 3 \mathrm{H}, \mathrm{Ar}-\mathrm{H}), 5.11\left(\mathrm{~s}, 2 \mathrm{H}, \mathrm{CH}_{2}\right), 1.29$ (s, 12H, $\left.\mathrm{CH}_{3}\right) .{ }^{11} \mathbf{B}$ NMR $\left(128 \mathrm{MHz}, 295 \mathrm{~K}, \mathrm{CDCl}_{3}\right): \delta / \mathrm{ppm} 21.1$ (s, Bpin). Values in agreement with literature. ${ }^{22}$
4,4,5,5-Tetramethyl-2-(neopentyloxy)-1,3,2-dioxaborolane (111). ${ }^{1}$ H NMR (400 MHz, $\left.295 \mathrm{~K}, \mathrm{CDCl}_{3}\right): \delta / \mathrm{ppm} 3.50\left(\mathrm{~s}, 2 \mathrm{H}, \mathrm{CH}_{2}\right.$ ), $1.07\left(\mathrm{~s}, 12 \mathrm{H}, \mathrm{CH}_{3}\right), 0.88\left(\mathrm{~s}, 9 \mathrm{H}, \mathrm{CH}_{3}\right) .{ }^{11} \mathbf{B}$ NMR $(128 \mathrm{MHz}$, $295 \mathrm{~K}, \mathrm{CDCl}_{3}$ ): $\delta /$ ppm 22.1 (s, BPin). Values in agreement with literature. ${ }^{48}$

\section{Conclusions}

This work has provided a series of crystallographic studies on a range of dithiaphosphole compounds. The solid-state structures of the halogen-containing species has revealed elongation in the $\mathrm{P}-\mathrm{X}$ bond (where $\mathrm{X}=$ halogen), with computational supporting extensive polarisation of the $\mathrm{P}-\mathrm{X}$ bond. These $P$-halo dithiaphospholes have then be used in a series of additional reactions. Crystallographic studies were then performed on these products. This was followed by a comparative study of the catalytic activity of these dithiaphospholes in relation to the corresponding dioxaphosphole and diazaphosphole compounds. Among those examined as metal-free pre-catalysts for the hydroboration of a series of aldehydes with HBpin, the phosphenium cation 1,3-diisopropyl-benzodiphosphenium triflate showed excellent conversion rates under mild conditions.

\section{Conflicts of interest}

There are no conflicts to declare.

\section{Acknowledgements}

RLM would like to acknowledge the EPSRC for an Early Career Fellowship (EP/R026912/1). JMR would like to thank NSERC for an operating grant (NSERC Discovery Grant RGPIN-201005523). We thank Dr A. D. Bond (Cambridge University) for assistance with the structure of compound 3 .

\section{Notes and references}

1 Main Group Strategies towards Functional Hybrid Materials, ed. T. Baumgartner and F. Jakle, Wiley, 2018.

2 Main Group Metals in Organic Synthesis, ed. H. Yamamoto and K. Oshima, Wiley, 2006.

3 S. Mukherjee and P. Thilagar, J. Mater. Chem. C, 2016, 4, 2647-2662.

4 Q. Tai, K. Tang and F. Yan, Energy Environ. Sci., 2019, 12, 2375-2405.

5 J. M. Rawson and C. P. Constantinides, in Chapter 4 in Spin in Organics, ed. J. S. Miller, World Scientific, 2018, vol. IV.

6 A. W. Cordes, R. C. Haddon and R. T. Oakley, Adv. Mater., 1994, 6, 798-802.

7 K. E. Preuss, Coord. Chem. Rev., 2015, 289-290, 49-61.

8 R. L. Melen, Science, 2019, 484, 479-484.

9 S. Yadav, S. Saha and S. S. Sen, ChemCatChem, 2016, 8, 486-501. 
10 A. R. Jupp and D. W. Stephan, Trends Chem., 2019, 1, 3548.

11 J. Zhang, J. Yang and J. Cheng, Angew. Chem., Int. Ed., 2019, 58, 5983-5987.

12 D. Gudat, A. Haghverdi and M. Nieger, Angew. Chem., Int. Ed., 2000, 39, 3084-3086.

13 S. Burck, D. Gudat, M. Nieger and W. Du Mont, J. Am. Chem. Soc., 2006, 128, 3946-3955.

14 C. C. Chong, H. Hirao and R. Kinjo, Angew. Chem., Int. Ed., 2014, 53, 3342-3346.

15 C. C. Chong, H. Hirao and R. Kinjo, Angew. Chem., Int. Ed., 2015, 54, 190-194.

16 C. H. Tien, M. R. Adams, M. J. Ferguson, E. R. Johnson and A. W. H. Speed, Org. Lett., 2017, 19, 5565-5568.

17 M. R. Adams, C. Tien, R. Mcdonald and A. W. H. Speed, Angew. Chem., Int. Ed., 2017, 56, 16660-16663.

18 S. Miaskiewicz, J. H. Reed, P. A. Donets, C. C. Oliveira and N. Cramer, Angew. Chem., Int. Ed., 2018, 57, 40394042.

19 B. Rao, C. C. Chong and R. Kinjo, J. Am. Chem. Soc., 2018, 140, 652-656.

20 T. Lundrigan, E. N. Welsh, T. Hynes, C. Tien, M. R. Adams, K. R. Roy, K. N. Robertson and A. W. H. Speed, J. Am. Chem. Soc., 2019, 141, 14083-14088.

21 T. T. P. Tran, D. M. C. Ould, L. C. Wilkins, D. S. Wright, R. L. Melen and J. M. Rawson, CrystEngComm, 2017, 19, 4696-4699.

22 D. M. C. Ould and R. L. Melen, Chem. - Eur. J., 2018, 24, 15201-15204.

23 M. Baudler, A. Moog, K. Glinka and U. Kelsch, Z. Naturforsch. B, 1973, 28, 363-369.

24 N. Burford, J. Passmore and M. J. Schriver, J. Chem. Soc., Chem. Commun., 1986, 140-142.

25 N. Burford, B. W. Royan, A. Linden and T. S. Cameron, J. Chem. Soc., Chem. Commun., 1988, 842-844.

26 N. Burford, B. W. Royan, A. Linden and T. S. Cameron, Inorg. Chem., 1989, 28, 144-150.

27 O. Kuhl, Phosphorus-31 NMR spectroscopy: A concise introduction for the synthetic organic and organometallic chemistry, Springer, Berlin, 2008.

28 F. H. Allen, D. G. Watson, L. Brammer, A. G. Orpen and R. Taylor, Typical interatomic distances: organic compounds, International Tables for Crystallography, 2006, ch. 9.5, vol. C, pp. 790-811.

29 D. M. C. Ould, A. C. Rigby, L. C. Wilkins, S. J. Adams, J. A. Platts, S. J. A. Pope, E. Richards and R. L. Melen, Organometallics, 2018, 37, 712-719.
30 T. S. Cameron and A. Linden, Phosphorus, Sulfur Silicon Relat. Elem., 1989, 41, 75-81.

31 S. C. Kosnik, M. C. Nascimento, J. M. Rawson and C. L. B. Macdonald, Dalton Trans., 2017, 46, 9769-9776.

32 I. V. Komlev, A. I. Zavalishina, I. P. Chernikevich, D. A. Predvoditelev and E. E. Nifantiev, Zh. Obshch. Khim., 1972, 42, 802-807.

33 E. E. Nifantiev, S. F. Sorokina, L. A. Vorobieva and A. A. Borisenko, Dokl. Akad. Nauk SSSR, 1982, 263, 900-910.

34 E. E. Nifantiev, N. S. Vyazankin, S. F. Sorokina, L. A. Vorobieva, O. A. Vyazankina, D. A. Bravo-Zhivotovsky and A. R. Bekker, J. Organomet. Chem., 1984, 277, 211-225.

35 C. Kirst, B. E. Bode, D. B. Cordes, P. S. Nejman, A. M. Z. Slawin, K. Karaghiosoff and J. D. Woollins, Dalton Trans., 2016, 45, 6348-6351.

36 E. G. Awere, N. Burford, R. C. Haddon, S. Parsons, J. Passmore, J. V. Waszczak and P. S. White, Inorg. Chem., 1990, 29, 4821-4830.

37 V. Naseri, R. Edge, R. J. Less, E. J. L. Mcinnes, K. Mu, J. M. Rawson and D. S. Wright, Chem. Commun., 2009, 1691-1693.

38 D. Förster, H. Dilger, F. Ehret, M. Nieger and D. Gudat, Eur. J. Inorg. Chem., 2012, 3989-3994.

39 O. Puntigam, I. Hajdók, M. Nieger, M. Niemeyer, S. Strobel and D. Gudat, Z. Anorg. Allg. Chem., 2011, 637, 988-994.

40 O. Puntigam, D. Förster, N. A. Giffin, S. Burck, J. Bender, F. Ehret, A. D. Hendsbee, M. Nieger, J. D. Masuda and D. Gudat, Eur. J. Inorg. Chem., 2013, 2041-2050.

41 N. A. Gi, A. D. Hendsbee, T. L. Roemmele, M. D. Lumsden, C. C. Pye and J. D. Masuda, Inorg. Chem., 2012, 51, 1183711850.

42 J. M. Slattery, C. Fish, M. Green, T. N. Hooper, J. C. Jeffery, R. J. Kilby, J. M. Lynam, J. E. Mcgrady, D. A. Pantazis, C. A. Russell and C. E. Willans, Chem. - Eur. J., 2007, 13, 6967-6974.

43 O. Nuyken and S. D. Pask, Polymers, 2013, 5, 361-403.

44 M. R. Adams, C. H. Tien, B. S. N. Huchenski, M. J. Ferguson and A. W. H. Speed, Angew. Chem., Int. Ed., 2017, 56, 6268-6271.

45 T. Hynes, E. N. Welsh, R. McDonald, M. J. Ferguson and A. W. H. Speed, Organometallics, 2018, 37, 841-844.

46 A. H. Cowley, R. E. Davis and P. E. Riley, Inorg. Chem., 1981, 20, 1179-1181.

47 W. Wang, X. Shen, F. Zhao, H. Jiang, W. Yao, S. A. Pullarkat, L. Xu and M. Ma, J. Org. Chem., 2018, 83, 69-74.

48 M. K. Barman, K. Das and B. Maji, J. Org. Chem., 2019, 84, 1570-1579. 